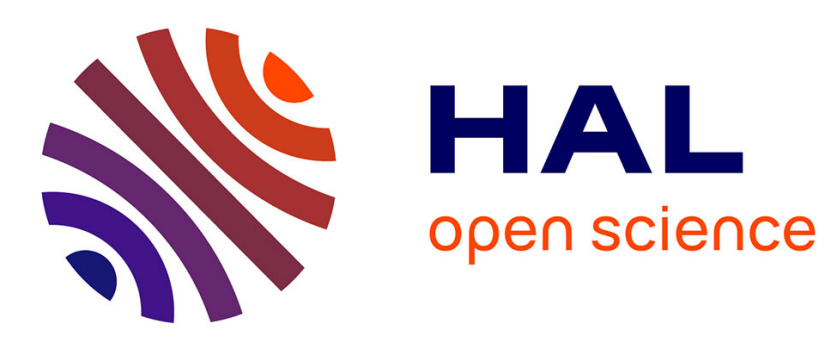

\title{
Brittle/ductile deformation of eclogites: insights from numerical models
}

Philippe Yamato, Thibault Duretz, Samuel Angiboust

\section{To cite this version:}

Philippe Yamato, Thibault Duretz, Samuel Angiboust. Brittle/ductile deformation of eclogites: insights from numerical models. Geochemistry, Geophysics, Geosystems, 2019, 20 (7), pp.3116-3133. 10.1029/2019GC008249 . insu-02135390

\section{HAL Id: insu-02135390 https://hal-insu.archives-ouvertes.fr/insu-02135390}

Submitted on 3 Jul 2019

HAL is a multi-disciplinary open access archive for the deposit and dissemination of scientific research documents, whether they are published or not. The documents may come from teaching and research institutions in France or abroad, or from public or private research centers.
L'archive ouverte pluridisciplinaire $\mathbf{H A L}$, est destinée au dépôt et à la diffusion de documents scientifiques de niveau recherche, publiés ou non, émanant des établissements d'enseignement et de recherche français ou étrangers, des laboratoires publics ou privés. 


\section{Geochemistry, Geophysics, Geosystems}

\author{
RESEARCH ARTICLE \\ 10.1029/2019GC008249 \\ Key Points: \\ - Evidence of brittle features in \\ eclogites does not necessarily mean \\ that they underwent extreme \\ (seismic) strain rate \\ - Deformation style analysis in \\ eclogite samples can provide an \\ estimate of the effective stress \\ sustained by these rocks \\ - Effective stress levels sustain by rock \\ can be high (i.e., up to $1.0 \mathrm{GPa}$ at 2.0 \\ $\mathrm{GPa}$ and $550{ }^{\circ} \mathrm{C}$ )
}

Supporting Information:

- Supporting Information S1

Correspondence to:

P. Yamato,

philippe.yamato@gmail.com

Citation:

Yamato, P., Duretz, T., \& Angiboust, S. (2019). Brittle/ductile deformation of eclogites: Insights from numerical models. Geochemistry, Geophysics, Geosystems, 20. https://doi.org/10.1029/ 2019GC008249

Received 31 JAN 2019 Accepted 2 MAY 2019

Accepted article online 20 MAY 2019

(C)2019. American Geophysical Union. All Rights Reserved.

\section{Brittle/Ductile Deformation of Eclogites: Insights From Numerical Models}

\author{
P. Yamato ${ }^{1,2}$ iD, T. Duretz ${ }^{1}$ iD, and S. Angiboust ${ }^{3}$ iD \\ ${ }^{1}$ Univ Rennes, CNRS, Géosciences Rennes - UMR 6118, F-35000 Rennes, France, ${ }^{2}$ Institut Universitaire de France, Paris, \\ France, ${ }^{3}$ Universite de Paris, Institut de physique du globe de Paris, CNRS, F-75005 Paris, France
}

\begin{abstract}
How rocks deform at depth during lithospheric convergence and what are the magnitudes of stresses they experience during burial/exhumation processes constitute fundamental questions for refining our vision of short-term (i.e., seismicity) and long-term tectonic processes in the Earth's lithosphere. Field evidence showing the coexistence of both brittle and ductile deformation at high pressure-low temperature (HP-LT) conditions particularly fuels this questioning. We here present 2D numerical models of eclogitic rock deformation by simple shear performed at centimeter scale. To approximate the eclogite paragenesis, we considered the deformed medium as composed of two mineral phases: omphacite and garnet. We run a series of models at $2.0 \mathrm{GPa}$ and $550{ }^{\circ} \mathrm{C}$ for different background strain rates (from $10^{-14} \mathrm{~s}^{-1}$ to $10^{-8} \mathrm{~s}^{-1}$ ) and for different garnet proportions (from $0 \%$ to $55 \%$ ). Results show that whole rock fracturing can occur under $H P-L T$ conditions for strain rates larger than $\sim 10^{-10} \mathrm{~s}^{-1}$. This suggests that observation of brittle features in eclogites does not necessarily mean that they underwent extreme strain rate. Care should therefore be taken when linking failure of eclogitic rocks to seismic deformation. We also explore the ranges of parameters where garnet and omphacite are deforming with a different deformation style (i.e., frictional vs viscous) and discuss our results in the light of naturally deformed eclogitic samples. This study illustrates that effective stresses sustained by rocks can be high at these $P-T$ conditions. They reach up to $\sim \mathrm{GPa}$ for an entirely fractured eclogite and up to $\sim 500 \mathrm{MPa}$ for rocks that contain fractured garnet.
\end{abstract}

\section{Introduction}

\subsection{Background}

High pressure-low temperature (HP-LT) metamorphic rocks such as eclogites are crucial for our understanding of convergence zone dynamics as they record the evolution of pressure $(P)$ and temperature $(T)$ conditions sustained by rocks with time $(t)$. In addition to these $P-T-t$ data, $H P-L T$ rocks may also record the history of deformation occurring at HP-LT conditions (Angiboust et al., 2011; Fountain et al., 1994; Godard \& Van Roermund, 1995; Viete et al., 2018). This last point is, however, rarely highlighted while it is of upmost importance. Indeed, the way HP-LT rocks deformed can inform us on their rheological behavior and also on their strength and the stresses they can support at natural conditions (e.g., Stöckhert, 2002; Yamato \& Brun, 2017).

\subsection{Brittle Deformation of Metamorphic Rocks in HP-LT Conditions}

The assessment of the deformation of metamorphic rocks occurring in HP-LT conditions remains difficult. A reason for that is that deformation-related structures occurring during the burial stage and/or at the peak of metamorphism are often overprinted during exhumation. Fresh HP-LT rocks are therefore most of the time associated to undeformed metamorphic units thereby preserved and interpreted as the result of a rapid exhumation. This also suggests the development of localized shear zones capable to isolate and to preserve the HP-LT parageneses.

The development of localized shear zones has already been intensively studied both from field analyses (e.g., Angiboust et al., 2011; Boundy et al., 1992; Fossen \& Cavalcante, 2017; Philippot \& van Roermund, 1992; Scambelluri et al., 2017) and through numerical models (e.g., Duretz et al., 2014; Jessell et al., 2009; Kaus \& Podladchikov, 2006; Poliakov et al., 1993). Among them, several studies highlighted the importance of brittle precursors in the genesis of shear zones (e.g., Mancktelow, 2006; Menegon et al., 2017). Moreover, in addition to the fact that brittle deformation is a good candidate to localize deformation, it can also be related to seismic events that are known to occur in subduction zones. 

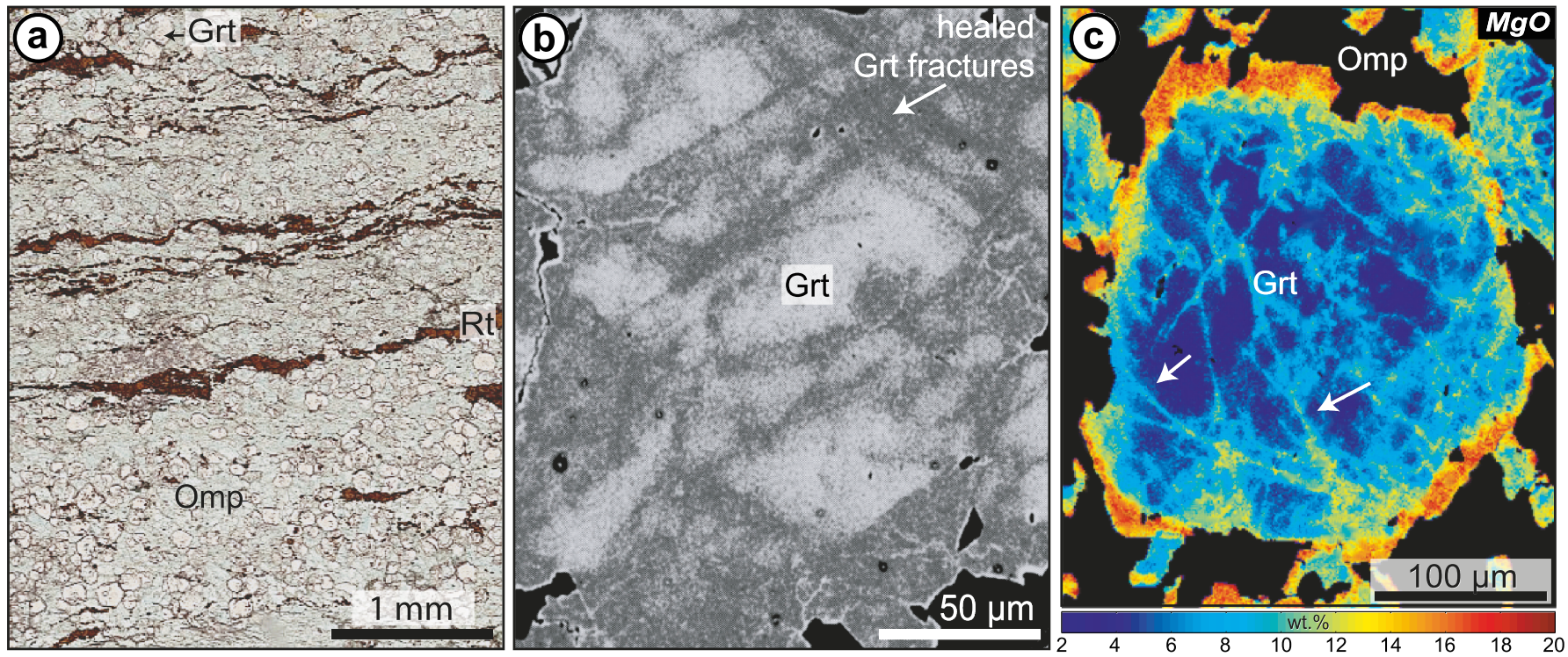

Figure 1. Evidence of brittle behavior in eclogites. (a) Eclogitized mylonitic mafic rock from the Lago Superiore unit (Monviso ophiolite, Western Alps) showing a strong foliation underlined by dark beds of rutile needles and flattened and parallelized omphacite-rich layers. Estimated garnet modal proportion is between 30 and $40 \mathrm{vol} \%$. (b) Scanning electron microscope (back scattered imaging mode) of a garnet crystal from a mylonitized eclogite from the Lago Superiore unit showing darker, healed fracture networks crosscutting brighter cores formed during burial of the oceanic lithosphere down to eclogite-facies conditions.

(c) X-ray chemical map of the MgO content of a garnet crystal from the Lago Superiore eclogite showing fossilized, Mg-richer healed fracture networks. Note that the Mg-rich outer garnet rim, interpreted as the thermal equilibration at peak burial conditions, transects and seals these fractures, which are hence interpreted as having formed slightly before peak burial (i.e., between 2 and $2.5 \mathrm{GPa}$; see Angiboust, Langdon, et al., 2012).

Evidence of brittle deformation in HP-LT condition is not rare. Pseudotachylytes formed in eclogite-facies conditions constitute the best examples (e.g., Austrheim \& Andersen, 2004; Austrheim \& Boundy, 1994; John \& Schenk, 2006). The description of eclogite breccias (e.g., Angiboust et al., 2012; Hertgen et al., 2017; Yang et al., 2014), fracturing at eclogite-facies conditions (e.g., Philippot, 1987) or oscillatory/rhythmic zoning found in minerals of HP-LT paragenesis (e.g., García-Casco et al., 2002; Viete et al., 2018), constitutes other potential indices suggesting brittle deformation in HP-LT conditions (Figure 1).

However, the mechanisms leading to such brittle behavior are still poorly constrained. The origin of brittle deformation events occurring in HP-LT metamorphic rocks is still an open question (e.g., Hertgen et al., 2017; Jamtveit et al., 2016; Shi et al., 2018). Brittle features are often seen as the result of short and high strain rate events associated to seismicity (Scambelluri et al., 2017; Trepmann \& Stöckhert, 2002). Some brittle features, possibly related with dehydration processes, have been also interpreted as the record of potential episodic slip events (Behr et al., 2018). One of the challenges is especially to decipher whether brittle features are triggered by hydrofracturing (e.g., Hacker et al., 2003; Jung et al., 2004), that is, rock failure results in fluid pressure increase (Figure 2a) or can nucleate without involving fluids (Incel et al., 2017). Without fluids, rock failure can be due either by a change in material properties (e.g., frictional weakening, Figure $2 b$ ) or simply by reaching a critical stress (Figure 2c). Characterizing the mechanisms leading to brittle deformation is therefore crucial since they involve very different stress levels. Important fluid pressure indeed limits the differential stress (Figure 2a), while conversely frictional behavior requires high stress concentration (Figure 2c). Therefore, the consequences go even beyond the understanding of the fracturing mechanism, because in presence of high differential stresses, the pressure recorded in metamorphic rocks could significantly deviate from lithostatic conditions (Mancktelow, 2008; Petrini \& Podladchikov, 2000), which may challenge conventional interpretation of $P-T$ data.

\subsection{Motivation of This Study}

The aim of this study is to test the conditions that can lead to the frictional deformation of eclogites under shearing at HP-LT conditions in fluid-absent conditions and without mineral transformations. The choice of eclogite material was stimulated by the fact that it can be simplified as the mixing of only two mineral phases: garnet and omphacite. 
(a)

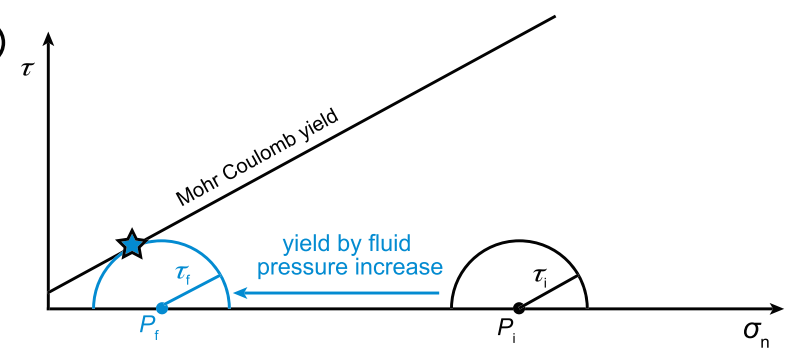

(b)

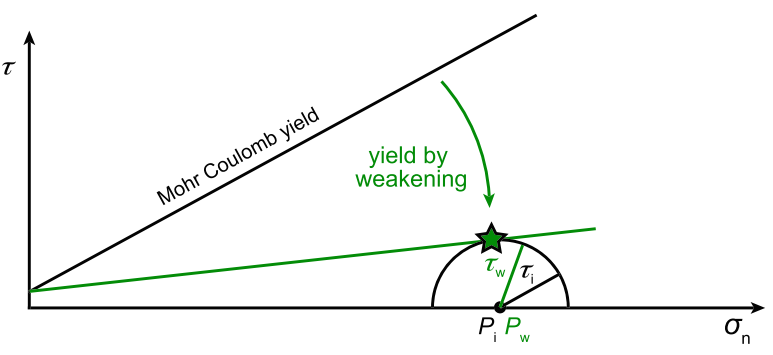

(C)

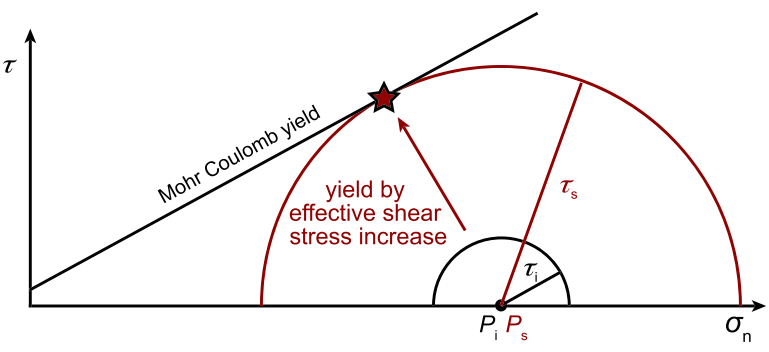

Figure 2. Mohr diagrams (normal stress $\sigma_{\mathrm{n}}$ vs shear stress $\tau$ ) presenting three possibilities to reach failure criterion for a rock initially at a pressure $P_{\mathrm{i}}$ and with a given shear stress $\tau_{\mathrm{i}}$. Note that in these diagrams, the stress convention is taken such as positive values indicate compression. The Mohr-Coulomb yield line is defined by the friction angle (slope) and the cohesion (value of $\tau$ at $\sigma_{\mathrm{n}}=0$ ) of the considered material. (a) Yielding by fluid pressure $\left(P_{\mathrm{f}}\right)$ : The shear stress $\tau_{\mathrm{f}}$ at failure (blue star) remains unchanged. (b) Yielding by weakening: Failure (green star) is due to a decrease of the friction angle. The pressure $\left(P_{\mathrm{W}}\right)$ and the shear stress $\left(\tau_{\mathrm{W}}\right)$ remain equal to $P_{\mathrm{i}}$ and $\tau_{\mathrm{i}}$, respectively. (c) Yielding by shear stress increase $\left(\tau_{\mathrm{s}}>\tau_{\mathrm{i}}\right)$ : Failure (red star) occurs without pressure change $\left(P_{\mathrm{s}}=P_{\mathrm{i}}\right)$.
To reach our goal, we designed a 2D numerical model allowing to analyze the deformation mechanisms involved as a function of background strain rate $\left(\dot{\varepsilon}_{\mathrm{BG}}\right)$ and garnet proportion, for a given background $P$ - $T$ condition corresponding to the eclogitic conditions. The term background is used here to define the surrounding conditions applied on the whole model either as initial or as boundary conditions. During the localization of deformation, depending on the local stress evolution and heat production due to the dissipative work (shear heating), the absolute values of strain rate, pressure, and temperature can vary locally, which constitutes another interesting aspect of our models.

A precise analysis of the deformation modes has then been carried out together with a quantification of effective stresses. This allows us to provide an evaluation of the effective strength of the rocks that can be linked to the final deformation features.

\section{Numerical Models for the Shearing of Centimeter-Scale Eclogite Samples}

We designed a direct centimeter-scale thermo-mechanical model (Figure 3) involving an eclogitic sample. The model is constituted of circular garnet crystals hosted in an omphacite matrix and is subjected to simple shear deformation. Background P-T conditions are fixed at $2.0 \mathrm{GPa}$ and $550{ }^{\circ} \mathrm{C}$. These values are within error compatible with near peak burial $P-T$ conditions estimated for Monviso Lago Superiore Unit eclogites (Figure 1, Angiboust et al., 2012; Groppo \& Castelli, 2010). These values are also representative of most peak $P$ conditions reached by oceanic eclogites worldwide (e.g., Agard et al., 2009; Ernst et al., 2007; Tsujimori \& Ernst, 2014). A large range of background strain rates (from $10^{-14} \mathrm{~s}^{-1}$ to $10^{-8} \mathrm{~s}^{-1}$ ) and different proportions of garnet content (from 0 to 55\%) have been tested.

To address the previously mentioned issues (section 1.3), the model needs (i) to take into account visco-elasto-frictional rheologies and (ii) a highresolution order to resolve the deformation of the smallest garnet crystals. Preliminary tests therefore need to be done to ensure the validity of our model.

In the following, we first describe the modeling method. We then propose two tests for our numerical code: (i) We numerically compute stress evolution at different strain rates for a single mineral phase and compare the results with exact solutions. (ii) We run a resolution test (i.e., we increase the numerical resolution until our results remain effectively unaffected) involving two mineral phases in order to determine the adequate resolution for this study.

\subsection{Methods}

The numerical models were designed using the 2D thermo-mechanical code MDoodz (Yamato et al., 2015). Kinematic simple shear (top to the right) is applied at the top and at the bottom of the model box (Figure 3). The left and right sides boundary conditions are periodic.

\subsubsection{Code Description}

Here we consider two-dimensional incompressible Stokes flow in the absence of body forces:

$$
\begin{aligned}
& -\frac{\partial P}{\partial x}+\frac{\partial \tau_{x x}}{\partial x}+\frac{\partial \tau_{x z}}{\partial z}=0 \\
& -\frac{\partial P}{\partial z}+\frac{\partial \tau_{z z}}{\partial z}+\frac{\partial \tau_{z x}}{\partial x}=0
\end{aligned}
$$




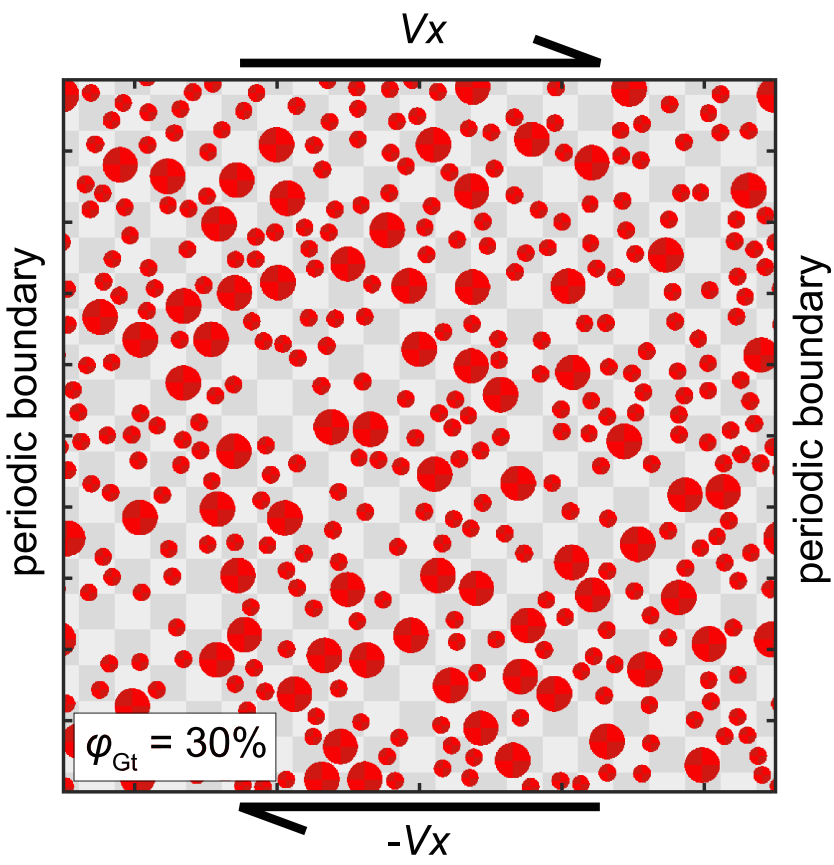

Figure 3. Model setup. The size of the model is $10 \times 10 \mathrm{~cm}$. Garnet crystals (reddish circles) are randomly dispersed in the omphacite matrix (in gray). Dark and light shades are for visualization; they do not correspond to different properties. Garnet crystals sizes are 5 and $2.5 \mathrm{~mm}(50-50 \%$ in proportions). Kinematic boundary conditions of simple shear are applied at the top and at the bottom of the model to impose a constant strain rate. The temperature is also kept constant at the top and at the bottom of the model. The left and the right sides of the model box are submitted to periodic boundary conditions (for both mechanics and energy equations).

$$
\frac{\partial U_{x}}{\partial x}+\frac{\partial U_{z}}{\partial z}=0
$$

where $P$ and $\tau_{i j}$ are the pressure and the deviatoric stress tensor, respectively. Note that in these continuum mechanics equations, stresses are defined as negative in compression. $U_{x}$ and $U_{z}$ are the two components of the velocity vector in $2 \mathrm{D}(x, z)$ Cartesian coordinate system. The temperature evolution equation takes the form of

$$
\rho C_{p} \frac{D T}{D t}=\frac{\partial}{\partial x}\left(k \frac{\partial T}{\partial x}\right)+\frac{\partial}{\partial z}\left(k \frac{\partial T}{\partial z}\right)+H_{\mathrm{s}}
$$

where $T$ is the temperature, $k$ is the thermal conductivity, $\rho$ is the density, and $C_{p}$ is the heat capacity at fixed pressure. $H_{\mathrm{s}}$ corresponds to the shear heating and is defined as the inner product of the deviatoric stress $\left(\tau_{i j}\right)$ and visco-plastic strain rate tensors $\left(\dot{\varepsilon}_{i j}^{\mathrm{VP}}\right)$ :

$$
H_{\mathrm{s}}=\dot{\varepsilon}_{i j}^{\mathrm{VP}} \tau_{i j}
$$

These equations are discretized over a square model domain using staggered grid finite differences. The spatial discretization of the material properties on the grid (rheological and thermal parameters) is provided via Lagrangian markers (Gerya \& Yuen, 2003). At each time step, material and thermal properties defined on the markers are interpolated to the nodes in the finite difference mesh using a distance-dependent interpolation (1-cell interpolation; see Yamato et al., 2012) to solve the Stokes problem (equations (1)-(3)) and the heat equation (equation (4)). All markers positions are evolved forward in time using a fourth order (in space) Runge-Kutta scheme (with a Courant number set to 0.2).

\subsubsection{Rheologies and Deformation Partitioning Calculation}

All the material properties and thermal parameters used for both garnet and omphacite in our study are presented in Table 1 . In our model, garnet and omphacite can deform in three ways: elastically (Hooke's law), viscously by dislocation creep, and frictionally following a Drucker-Prager law. Diffusion creep for omphacite (Hier-Majumder et al., 2005) is not included as it is not activated in the range of the strain rate tested (from $10^{-14} \mathrm{~s}^{-1}$ to $10^{-6} \mathrm{~s}^{-1}$ ) and for grain sizes $>1 \mathrm{~nm}$ at $2.0 \mathrm{GPa}$ and $550{ }^{\circ} \mathrm{C}$ (see supporting information Figure S1). Although pressure-solution mechanisms have been identified in some natural HP-LT eclogitic samples (Bascou et al., 2001; Hertgen et al., 2017; Mauler et al., 2001; Philippot \& van Roermund, 1992), laboratory data for omphacite pressure-solution creep could not be found in the literature. The results presented here therefore assume that dislocation creep is the only creep mechanism occurring at $2.0 \mathrm{GPa}$ and $550{ }^{\circ} \mathrm{C}$.

At a given $P$ - $T$ condition, it is possible to evaluate the deformation mechanism activated depending on the background strain rate $\left(\dot{\varepsilon}_{\mathrm{II}}\right)$. The simplest manner is to evaluate the effective stress for each mechanism. Hence, considering a Drucker-Prager law for the frictional behavior, the shear stress value for the yield $\left(\tau_{\mathrm{y}}\right)$ can be expressed as follows:

$$
\tau_{\mathrm{y}}=C \cos (\varphi)+P \sin (\varphi)
$$

where $P$ is pressure (corresponding to the negative of mean stress), and $C$ and $\varphi$ are the cohesion and the friction angle of the material, respectively (see Table 1).

The flow stress $\left(\tau_{\mathrm{f}}\right)$ for dislocation creep can be expressed as

$$
\tau_{\mathrm{f}}=2 F_{\mathrm{pwl}} A^{-\frac{1}{n}} \exp \left(\frac{E_{\mathrm{a}}}{n R T}\right) \dot{\varepsilon}_{\mathrm{II}}^{\frac{1}{n}}
$$

where $n, A$, and $E_{\mathrm{a}}$ are the dislocation creep parameters of the material (see Table 1) and $R$ is the universal gas constant $\left(R=8.314510 \mathrm{~J} \cdot \mathrm{K}^{-1} \cdot \mathrm{mol}^{-1}\right)$. $F_{\text {pwl }}$ corresponds to the correction factor (e.g., Schmalholz \& 
Table 1

Parameters Used in This Study

\begin{tabular}{|c|c|c|c|c|}
\hline Parameters & Symbol & Units & Omphacite & Garnet \\
\hline \multicolumn{5}{|c|}{ Dislocation creep properties } \\
\hline Reference & & & Zhang et al. (2006) & Ji and Martignole (1994) \\
\hline Preexponential factor & $A$ & $\mathrm{~Pa}^{-\mathrm{n}} \cdot \mathrm{s}^{-1}$ & $1.0 \times 10^{-23}$ & $2.7952 \times 10^{-7}$ \\
\hline Exponent & $n$ & - & 3.5 & 2.22 \\
\hline Activation energy & $E_{\mathrm{a}}$ & $\mathrm{kJ} \cdot \mathrm{mol}^{-1}$ & 310.0 & 485.0 \\
\hline \multicolumn{5}{|l|}{ Elastic properties } \\
\hline Shear modulus & $G$ & $\mathrm{~Pa}$ & $10^{10}$ & $10^{10}$ \\
\hline \multicolumn{5}{|c|}{ Drucker-Prager plasticity } \\
\hline Cohesion & $C$ & $\mathrm{~Pa}$ & $50 \times 10^{6}$ & $50 \times 10^{6}$ \\
\hline Friction & $\varphi$ & $\circ$ & 30 & 30 \\
\hline \multicolumn{5}{|c|}{ Thermal related properties } \\
\hline Density & $\rho$ & $\mathrm{kg} \cdot \mathrm{m}^{-3}$ & 3300 & 3700 \\
\hline Heat capacity & $C p$ & $\mathrm{~J} \cdot \mathrm{kg}^{-1} \cdot \mathrm{K}^{-1}$ & 1050 & 1050 \\
\hline Conductivity & $k$ & $\mathrm{~W} \cdot \mathrm{m}^{-1} \cdot \mathrm{K}^{-1}$ & 2.3 & 2.3 \\
\hline
\end{tabular}

Note. Shear modulus and thermal properties are considered the same both for garnet and omphacite. The chosen values are in the range of values proposed for the properties of rocks (e.g., Turcotte \& Schubert, 2014). Friction angle and cohesion are set to be representative of the Byerlee's law (Byerlee, 1978).

Fletcher, 2011) for invariant formulation relative to the type of experiments used for calibration (here axial compression) such as

$$
F_{\mathrm{pwl}}=\frac{1}{6} 2^{\frac{1}{n}} 3^{\frac{n-1}{2 n}}
$$

Here we use a visco-elasto-frictional rheological model. The contribution of each deformation mechanism is computed iteratively in order to satisfy the following Maxwell model (e.g., Popov \& Sobolev, 2008):

$$
\dot{\varepsilon}_{i j}=\dot{\varepsilon}_{i j} \mathrm{v}+\dot{\varepsilon}_{i j} \mathrm{e}^{\mathrm{e}}+\dot{\varepsilon}_{i j}^{\mathrm{p}}
$$

where the $\mathrm{v}$, e and $\mathrm{p}$ superscripts refer to the viscous, elastic, and plastic (frictional) amounts of strain rate. The viscous strain rate $\left(\dot{\varepsilon}_{i j}{ }^{\mathrm{V}}\right)$ is computed using equation (7) as

$$
\dot{\varepsilon}_{i j}{ }^{\mathrm{v}}=\dot{\varepsilon}_{\mathrm{II}}{ }^{\mathrm{v}} \frac{\tau_{i j}}{\tau_{\mathrm{II}}}=A\left[2 F_{\mathrm{pwl}} \exp \left(\frac{E_{\mathrm{a}}}{n R T}\right)\right]^{-n} \tau_{\mathrm{f}}{ }^{n} \frac{\tau_{i j}}{\tau_{\mathrm{II}}}
$$

The elastic strain rate is expressed following the Hooke's law as

$$
\dot{\varepsilon}_{i j} \mathrm{e}=\frac{\dot{\tau}_{i j}}{2 G} \frac{\tau_{i j}}{\tau_{\mathrm{II}}}
$$

where $G$ is the shear modulus (see Table 1 ) and by computing the time derivative of the deviatoric stresses by using the stresses from the previous time step. The strain rate for frictional plasticity is computed by using equation (6) such as

$$
\dot{\varepsilon}_{i j} \mathrm{p}=\dot{\varepsilon}_{\mathrm{II}} \mathrm{p} \frac{\tau_{i j}}{\tau_{\mathrm{II}}}=\left[\dot{\varepsilon}_{\mathrm{II}}-\frac{\dot{\tau}_{\mathrm{II}}}{2 G}-\frac{\tau_{\mathrm{II}}}{2 \eta}\right] \frac{\tau_{i j}}{\tau_{\mathrm{II}}}
$$

where $\tau_{\mathrm{II}}=\tau_{\mathrm{y}}$ and $\dot{\tau}_{\mathrm{II}}$ are evaluated at the yield criterion. This contribution of frictional plasticity is only computed when the yield criterion is met.

The effective viscosity $(\eta)$, which relates the deviatoric stress tensor and the strain rate tensor, is computed once equation (9) is satisfied and takes the form of 


$$
\eta=\frac{\tau_{i j}}{2 \dot{\varepsilon}_{i j}}=\frac{\tau_{\mathrm{II}}}{2 \dot{\varepsilon}_{\mathrm{II}}}
$$

The effective stress of the sample ( $\left.\tau_{\text {eff }}\right)$ is computed by integrating $\tau_{\mathrm{II}}$ over the model domain such as

$$
\tau_{\text {eff }}=\frac{1}{S} \int_{0}^{S} \tau_{\mathrm{II}} \mathrm{d} S
$$

where $S$ corresponds to the model area. For mono-mineral cases at homogeneous stress $\tau_{\text {eff }}=\tau_{\mathrm{II}}$. This value of $\tau_{\text {eff }}$ will be used then to characterize the strength of our sample through time. Here we consider that all material properties are constant; hence, we do not apply any form of strain softening.

\subsection{Tests With Mono-Mineralic Samples}

$P-T$ diagrams showing the value of the effective stress $\left(\tau_{\text {eff }}\right)$ computed from equations $(6)$ and (7) are presented in Figure 4a for pure omphacite and in Figure $4 \mathrm{~b}$ for pure garnet. These diagrams illustrate well the pressure dependency of $\tau_{\text {eff }}$ in the frictional field and the temperature dependency of $\tau_{\text {eff }}$ in the dislocation creep field. The limit between the two deformation mechanisms (i.e., the brittle-ductile transition) is strain rate dependent as shown in Figure 4c. A first order analysis of this diagram shows that at $2.0 \mathrm{GPa}$ and $550{ }^{\circ} \mathrm{C}$, a rock constituted by both omphacite and garnet is frictional for a background strain rate $\dot{\varepsilon}_{\mathrm{BG}}$ $>10^{-10} \mathrm{~s}^{-1}$ (black star in Figure 4c). Frictional yielding occurs at $1.043 \mathrm{GPa}$.

When two mineral phases are considered, 2D numerical models become necessary to assess the effect of relative mineral proportions on the deformation mode. It is indeed essential to solve the momentum equations in order to resolve the state of stress in time and space and to monitor the dynamic evolution of deformation.

We first verify that our 2D models reproduce results from $0 \mathrm{D}$ predictions in a mono-mineralic limit for a given $P-T-\dot{\varepsilon}_{\mathrm{BG}}$ condition. By considering equations (9) to (14) and by using the material parameters used for this study (Table 1$)$, one may predict loading curves $\left(\tau_{\text {eff }}=\mathrm{f}(t)\right.$ or shear strain $\gamma$ ). The conversion of the time into shear strain in our $2 \mathrm{D}$ models being computed as $\gamma_{\mathrm{BG}}=2 t \dot{\varepsilon}_{\mathrm{BG}}$. The comparison between the obtained results and the 0D solution is presented in supporting information Figure S2. Our 2D model accurately fits the predictions for both the effective stress and deformation partitioning. This last point is illustrated by the viscous component observed in Figure S2a at a background strain rate of $10^{-10} \mathrm{~s}^{-1}$ in omphacite before plastic/frictional yield around a $\gamma$ of 0.1 . All results coincide also for garnet that always has an elasto-frictional behavior.

\subsection{Modeling of the Eclogitic Rocks Shearing}

We now focus on the effective stress and deformation patterns that arise when considering two mineral phases.

\subsubsection{Initial and Boundary Conditions}

The initial setup (Figure 3) involves circular garnet crystals hosted in an omphacite matrix. These crystals are distributed randomly within the model box. We purposely used two different crystal populations characterized by different sizes. Such configuration allows to reach a maximum of $\sim 55 \%$ of garnet content. The model box is subjected to periodic simple shear deformation as in the previous tests.

\subsubsection{Resolution Tests}

The smaller considered garnet crystals have a diameter of $2.5 \mathrm{~mm}$ (Figure 3). The resolution of our computational grid needs to be fine enough in order to correctly resolve these crystals. We hence performed a resolution test involving resolutions of $250^{2}$ nodes to $1,500^{2}$ nodes. Models were computed for different strain rates (see supporting information Figures S3 and S4). They show that above a resolution of $750^{2}$ nodes, that is, a mesh of $150 \mu \mathrm{m}$, all the models provide very similar results. Figure S4 depicts effective stress curves, which well illustrates the convergence of the results above a resolution of $750^{2}$. Structural softening occurs when the effective stress reaches the yield value $(1.043 \mathrm{GPa})$, and it happens earlier as the resolution is increased. This relative difference however diminishes as the resolution is increased. For our study, we thus performed all the simulations by using a grid constituted of $1,000^{2}$ nodes. This provides models with a mesh resolution of $100 \mu \mathrm{m}$ (i.e., $\sim 25$ cells equal to the diameter of the smallest garnet crystals). 
(a)

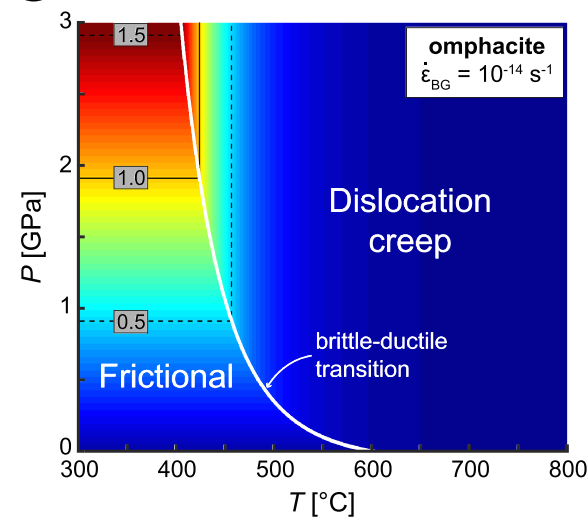

(b)

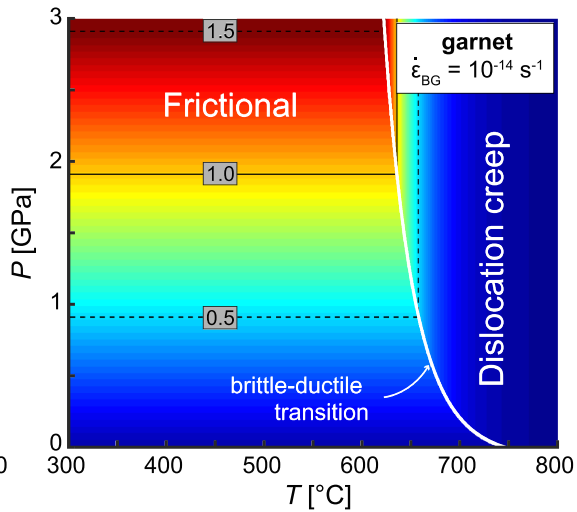

(c)

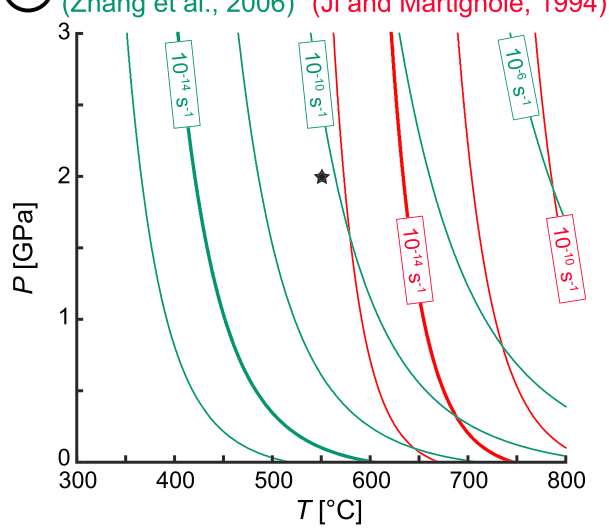

brittle-ductile transition $=\mathrm{f}\left(\dot{\varepsilon}_{\mathrm{BG}}\right)$

Figure 4. Second deviatoric stress invariant $\tau_{\mathrm{II}}$ in a $P$ - $T$ diagram for (a) omphacite and (b) garnet. For this figure, $\tau_{\mathrm{II}}$ is computed from equations (6) and (7) such as $\tau_{\mathrm{II}}=\min \left(\tau_{\mathrm{y}}, \tau_{\mathrm{f}}\right)$. (c) Limit between the frictional and dislocation creep fields as a function of the strain rate for omphacite (green) and garnet (red). Space between lines is of $100 \mathrm{~s}^{-1}$. The black star corresponds to the $P$-T conditions considered in this study $\left(2.0 \mathrm{GPa}, 550{ }^{\circ} \mathrm{C}\right)$.

\section{Results}

The parametric study was performed for background strain rates $\left(\dot{\varepsilon}_{\mathrm{BG}}\right)$ varying from $10^{-14} \mathrm{~s}^{-1}$ to $10^{-8} \mathrm{~s}^{-1}$, and for garnet proportions of $1,10,20,30,40,50$, and 55\% (Figure $5 \mathrm{a}$ ). The obtained results can be grouped together in three different domains (Figure 5) depending on the resulting deformation regime of the rock:

1. the omphacite matrix deforms viscously (i.e., following the dislocation creep power law), and the garnet crystals remain elastic;

2. the omphacite matrix deforms viscously, and the garnet crystals behave in a brittle manner (i.e., as an elasto-plastic material); and

3. the entire rock behaves in a brittle manner.

(a)

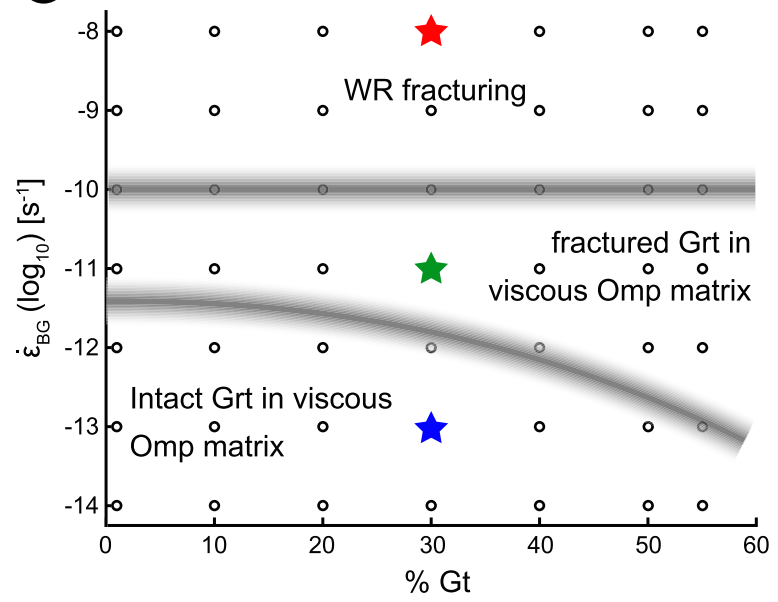

Effective stress evolution for three selected models $\left(30 \%\right.$ of garnet $\left./ 2.0 \mathrm{GPa} / 550^{\circ} \mathrm{C}\right)$

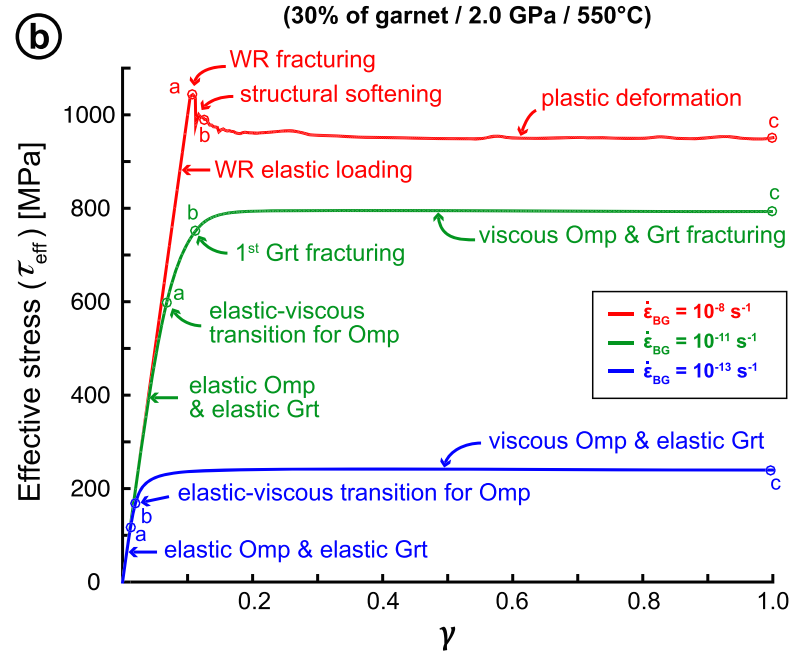

Figure 5. (a) Regime of deformation of the rock sample obtained in our models depending on the applied background strain rate and the garnet proportion. Dots correspond to the numerical simulations. Stars correspond to models presented in Figure 5b. Abbreviations: WR, whole rock; Grt, garnet; Omp, omphacite (b) Evolution of the effective stress for the three selected models presenting a garnet content of $30 \%$, a background pressure of $2.0 \mathrm{GPa}$, and a temperature of $550{ }^{\circ} \mathrm{C}$. Blue, green, and red lines thus corresponds to the results obtained (using equation (14)) for background strain rates of $10^{-13}, 10^{-11}$, and $10^{-8} \mathrm{~s}^{-1}$, respectively (stars shown in Figure 5a). For each model, dots labeled a, b and c refer to the snapshots presented in the figure dedicated to the model (i.e., blue $=$ Figure 6 , green $=$ Figure 7 , and red $=$ Figure 8 ) . 

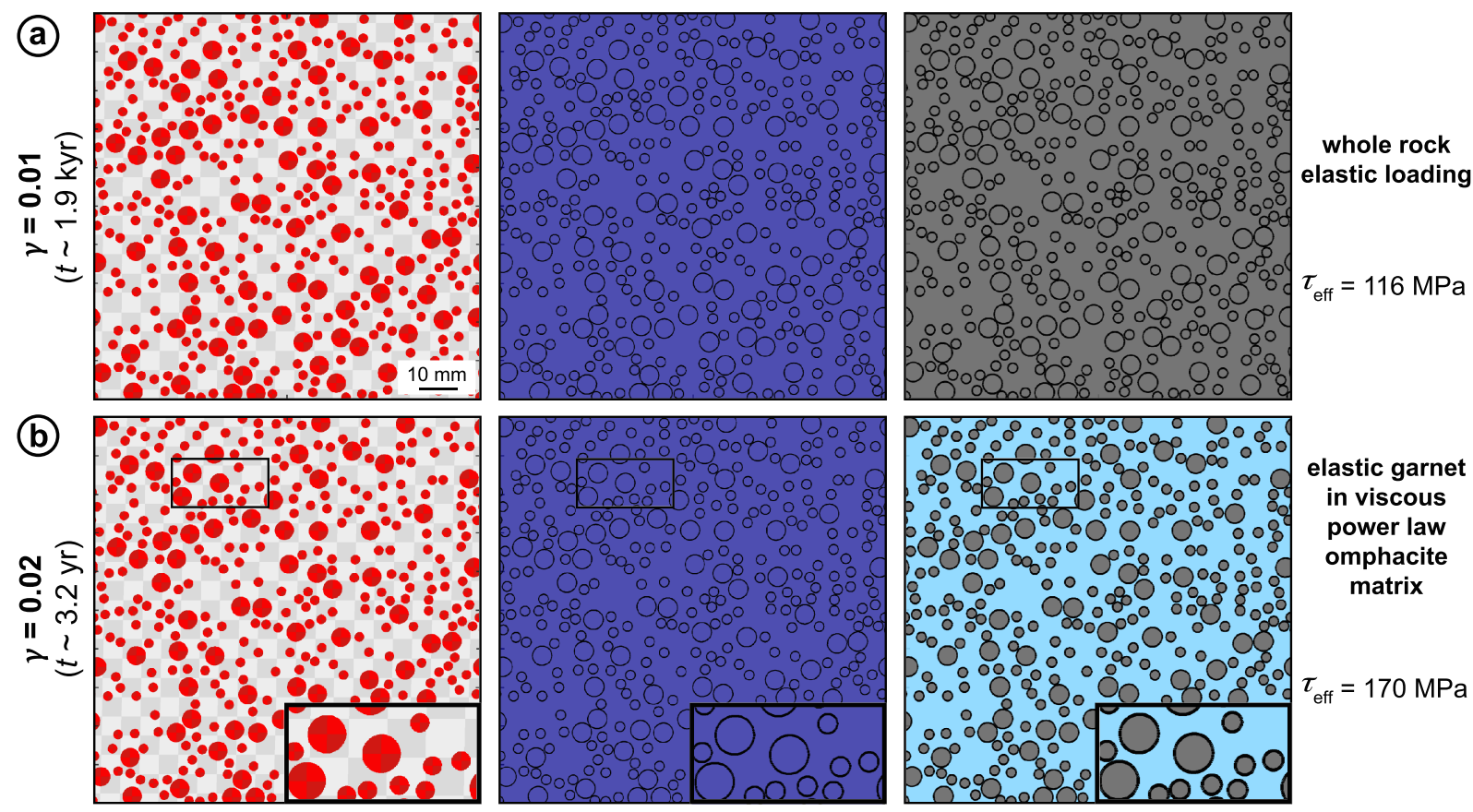

\section{elastic garnet}

in viscous

power law

omphacite

matrix

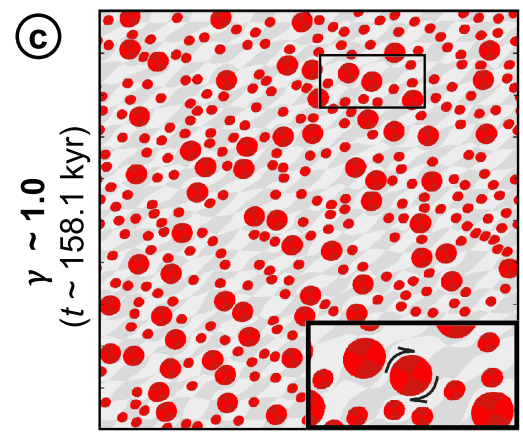

$\dot{\varepsilon}_{\mathrm{BG}}=10^{-13} \mathrm{~s}^{-1}$
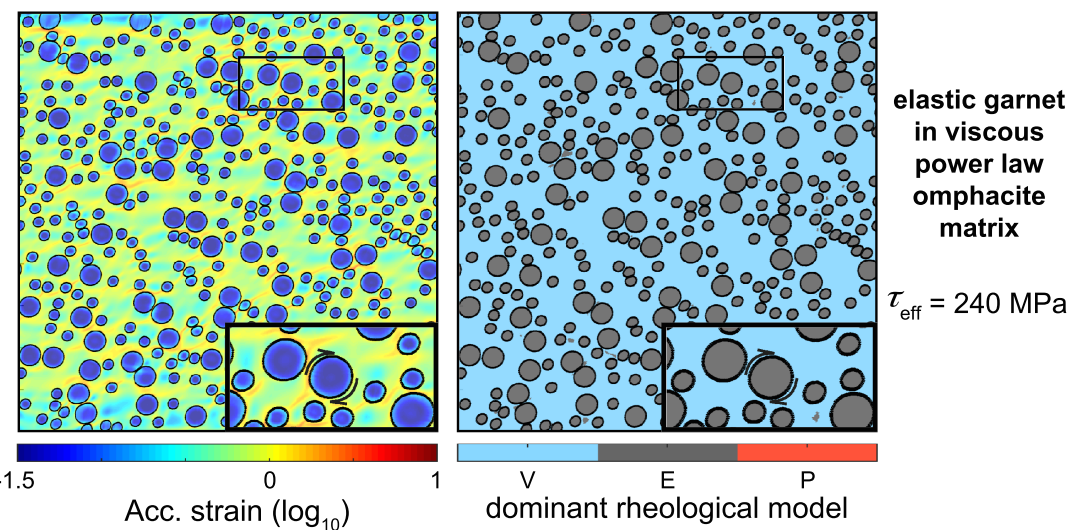

Figure 6. Model evolution for a background strain rate of $10^{-13} \mathrm{~s}^{-1}$. Evolution of phases (left), accumulated strain (middle), and dominant rheological model

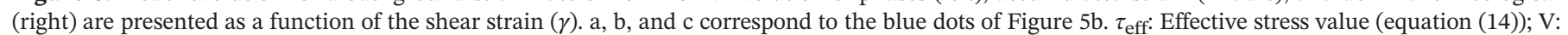

Viscous behavior (i.e., power law creep); E: Elastic; P: Plastic (i.e., frictional law: Drucker-Prager).

The distribution of these domains is mainly function of $\dot{\varepsilon}_{\mathrm{BG}}$; even if for low values, garnet proportion highly influences the results. These three regimes are described in more details in the following.

\subsection{Influence of the Strain Rate}

In order to illustrate the three different deformation regimes, three models are here presented in details for a garnet proportion fixed at $30 \%$. These three chosen examples are taken for imposed $\dot{\varepsilon}_{\mathrm{BG}}$ of $10^{-13} \mathrm{~s}^{-1}, 10^{-11} \mathrm{~s}$ ${ }^{-1}$, and $10^{-8} \mathrm{~s}^{-1}$. Figure $5 \mathrm{~b}$ presents the associated effective stress evolution and summarizes the different stages occurring during these simulations. The evolution of these three models is presented in detail, up to a shear strain $\gamma=1.0$, in Figures 6-8, respectively.

For an applied strain rate of $10^{-13} \mathrm{~s}^{-1}$ (blue line in Figure 5b) the whole sample first undergoes an elastic loading (blue circle labeled a on Figures 5b and 6a) until an effective stress value of $\sim 170 \mathrm{MPa}$ and a $\gamma$ of $\sim 0.02$ is attained (blue circle labeled $\mathrm{b}$ in Figure $5 \mathrm{~b}$ ). At this point, the deformation regime of the omphacite matrix becomes viscous and switches to power law dislocation creep (Figure 6b). After that, the rheological behavior of both omphacite matrix and garnet crystals remains the same. Garnet crystals behave as elastic 

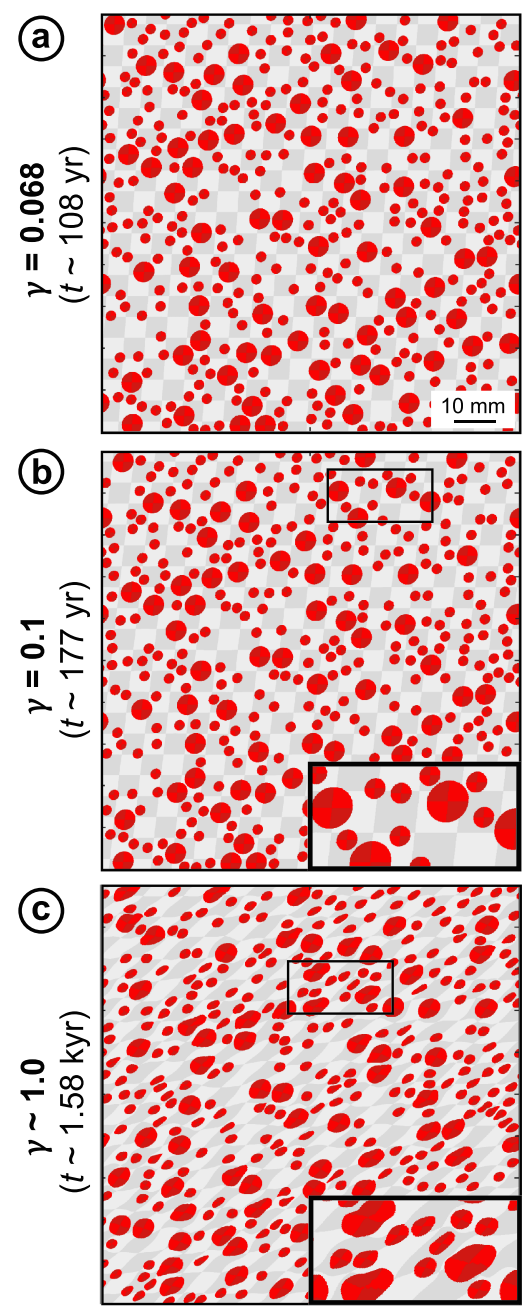

$\dot{\varepsilon}_{\mathrm{BG}}=10^{-11} \mathrm{~s}^{-1}$
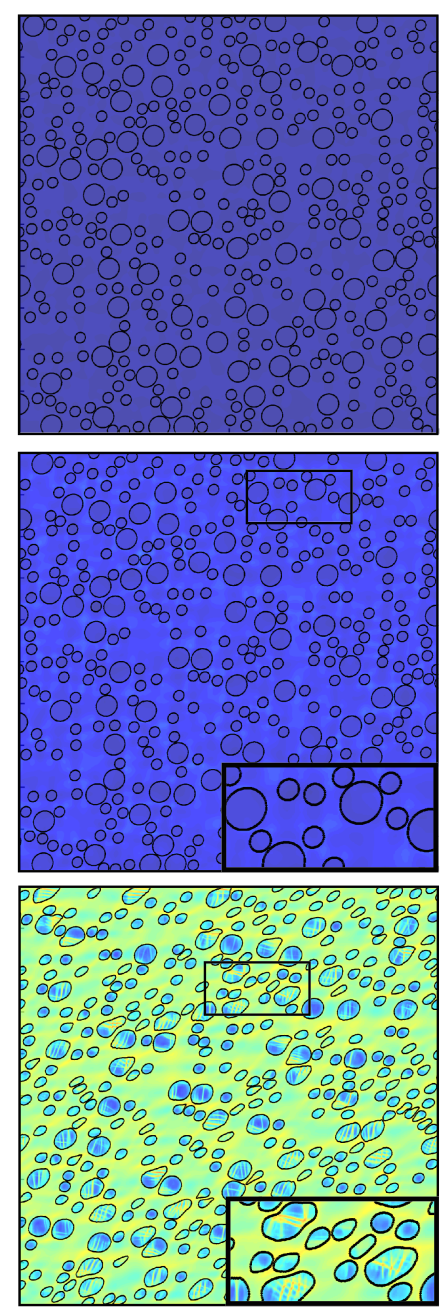

1.5
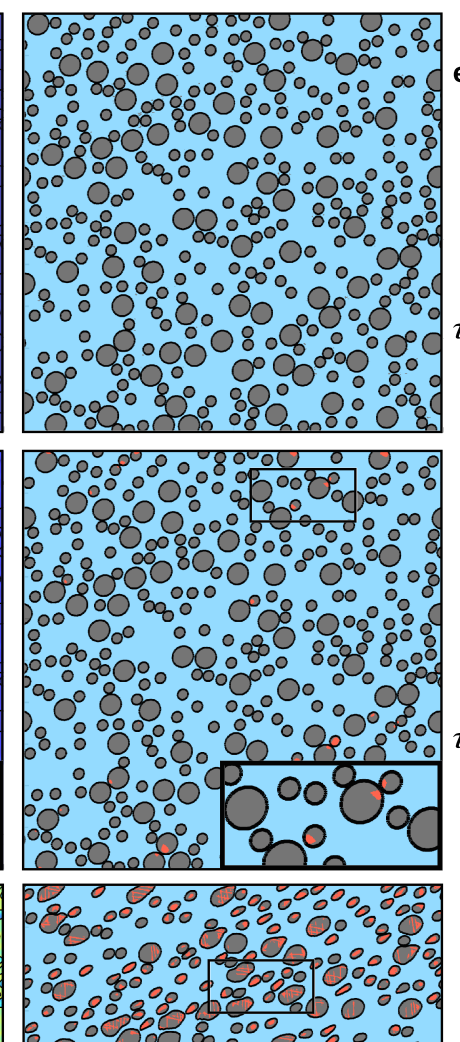

\section{0}

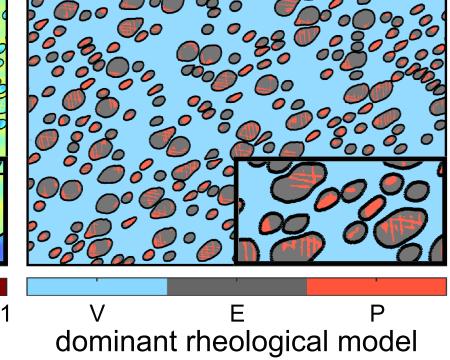

Figure 7. Model evolution for a background strain rate of $10^{-11} \mathrm{~s}^{-1}$. Evolution of phases (left), accumulated strain (middle), and dominant rheological model (right) are presented as a function of the shear strain $(\gamma)$. a, b, and c correspond to the green dots of Figure $5 \mathrm{~b}$. $\tau_{\text {eff: }}$ Effective stress value (equation (14)); V: Viscous behavior (i.e., power law creep); E: Elastic; P: Plastic (i.e., frictional law: Drucker-Prager).

bodies rotating in the viscous omphacite matrix, and strain is accommodated by the omphacite matrix (Figures $6 \mathrm{c}$ and $6 \mathrm{~d}$ ).

For a strain rate of $10^{-11} \mathrm{~s}^{-1}$ (green line in Figure $5 \mathrm{~b}$ ), elastic loading of the whole rock necessitates more strain $(\gamma=0.068$ ). At this $\gamma$ (dot labeled a in Figure $5 \mathrm{~b}$ ), the effective stress of the rock is of $599 \mathrm{MPa}$ and, as in the previous model, the omphacite matrix starts to deform in a viscous manner (Figure 7a). Garnet crystals remain elastic and rotate in the matrix until the stress, in some of them, becomes locally high enough to reach yielding, leading to garnet fracturing (green circle labeled $b$ in Figures $5 b$ and $7 b$ ). After this point, the rheological behavior of both omphacite matrix and garnet crystals remains the same. Garnet crystals keep on yielding and dismember within the viscous power law omphacite matrix (Figure 7c and 7d). A part of the strain is therefore accommodated also by garnet fracturing.

For an applied strain rate of $10^{-8} \mathrm{~s}^{-1}$ (red curve in Figure 5b), elastic loading lasts until a strain of 0.1 and a stress value of $1.043 \mathrm{GPa}$ is reached (red circle labeled a in Figure 5b). Shear banding through the whole sample then occurs (Figure 8a) and propagates (Figures $8 \mathrm{~b}$ and $8 \mathrm{c}$ ). This leads to a structural softening of the sample and a small drop of the effective stress (see Figure 5b). Frictional deformation then localizes at the edge of the model leaving the rest of the rock undeformed (Figure 8d). 

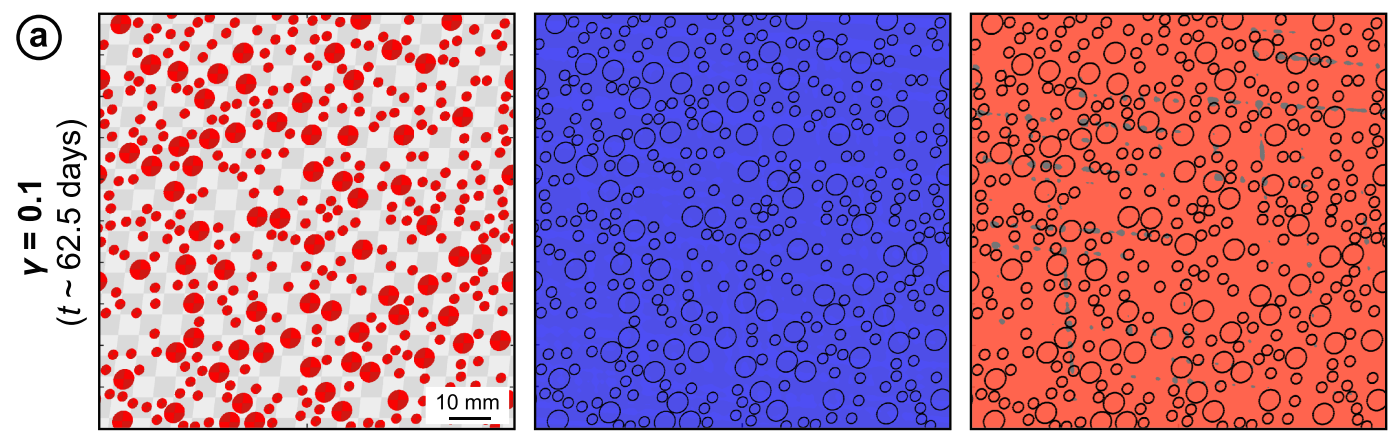

\section{whole rock \\ fracturing \\ just after \\ whole rock \\ elastic \\ loading}
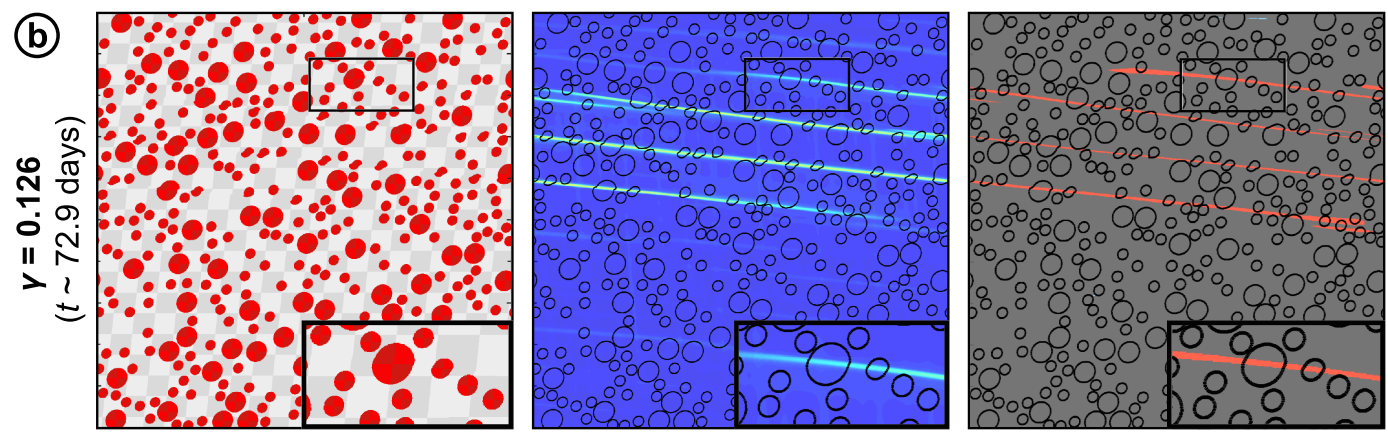

$\tau_{\text {eff }}=1043 \mathrm{MPa}$

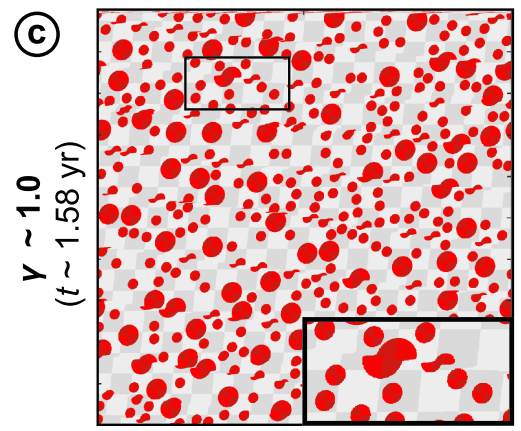

$\dot{\varepsilon}_{\mathrm{BG}}=10^{-8} \mathrm{~s}^{-1}$

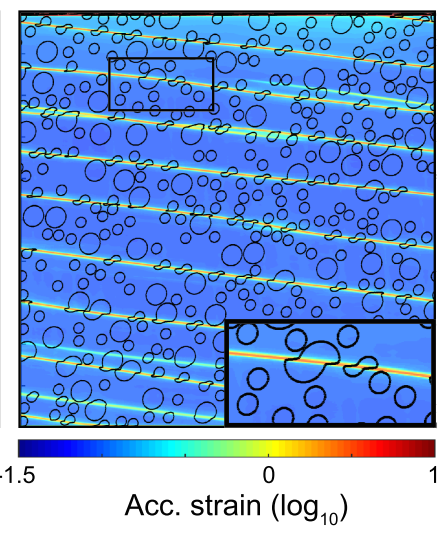

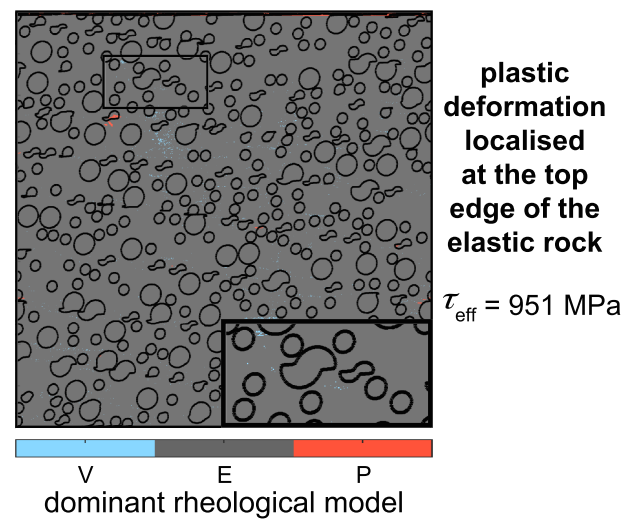

Figure 8. Model evolution for a background strain rate of $10^{-8} \mathrm{~s}^{-1}$. Evolution of phases (left), accumulated strain (middle), and dominant rheological model (right) are presented as a function of the shear strain $(\gamma)$. a, b, and c correspond to the red dots of Figure $5 \mathrm{~b}$. $\tau_{\text {eff: }}$ Effective stress value (equation (14)); V:

Viscous behavior (i.e., power law creep); E: Elastic; P: Plastic (i.e., frictional law: Drucker-Prager).

\subsection{Influence of Garnet Proportion}

For strain rates larger than $10^{-10} \mathrm{~s}^{-1}$, the entire sample follows a frictional behavior irrespective of the garnet content. The role of garnet proportions is only significant in the conditions where the omphacite matrix deforms viscously (Figure 5a). Figure 9 shows the influence of garnet proportion for models implying a $\dot{\varepsilon}_{\mathrm{BG}}$ of $10^{-12} \mathrm{~s}^{-1}$. At low garnet content ( $\left.\leq 30 \%\right)$, garnet crystals remain elastic in the viscous omphacite matrix. When garnet proportion increases, the number of possible interactions between garnet crystals increases and leads to an increase of the local stresses values (Figure 9). Such stress variations can be large enough to generate garnet yielding (see Figure 9, for garnet proportion $\geq 40 \%$ ). For a $\dot{\varepsilon}_{\mathrm{BG}}$ of $10^{-12} \mathrm{~s}^{-1}$, the transition between the two deformation regimes occurs for a garnet content of 35\% (Figure 5a). This transition is shifted up as the applied strain rate is decreased (see Figure 5a).

Moreover, garnet strength is higher than that of omphacite. For a given strain, an increase in garnet proportions requires to distribute it in a more and more reduced omphacite matrix. Strain is then concentrated and higher between garnet crystals. This is illustrated in Figure $9 \mathrm{c}$ where values of accumulated strain in the omphacite increase with the garnet proportion. The combination of these two effects (i.e., increase of both 
$01 \%$
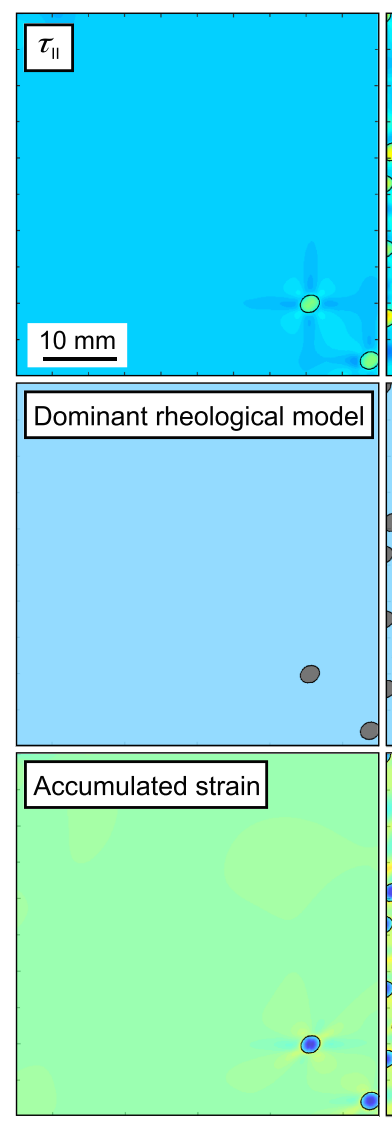

$\dot{\varepsilon}_{\mathrm{BG}}=10^{-12} \mathrm{~s}^{-1}$
$20 \%$
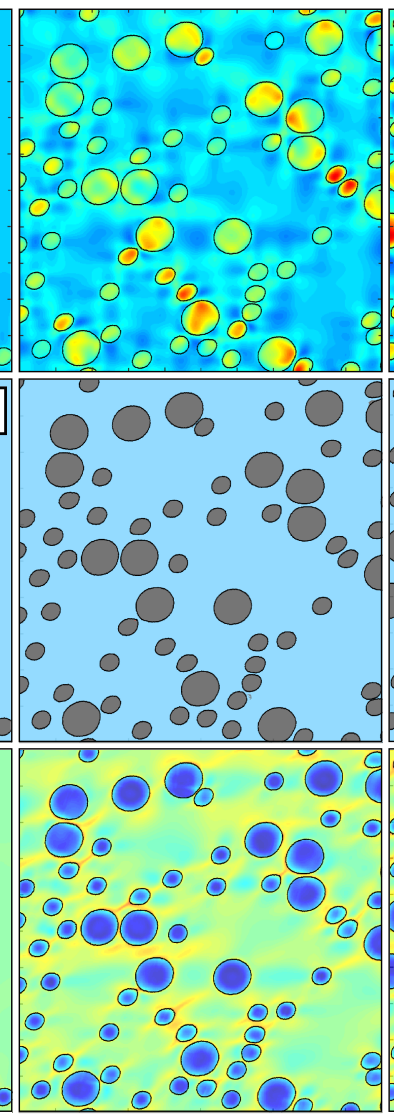

$0^{\circ}$

\section{$40 \%$}
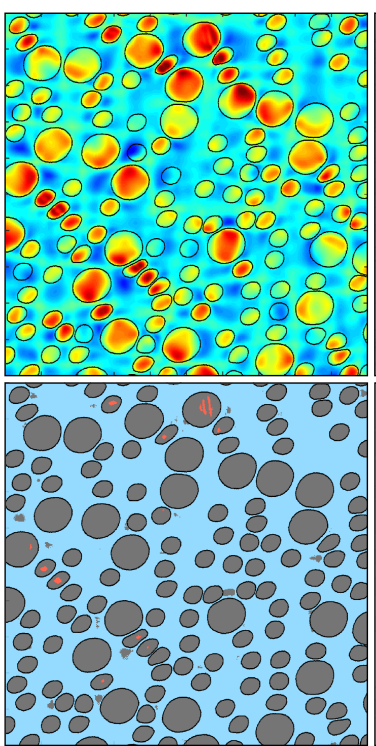

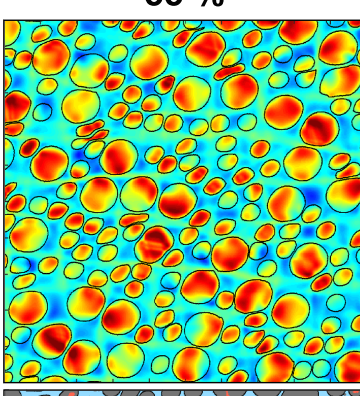

$\mathrm{GPa}$

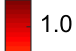

0.5
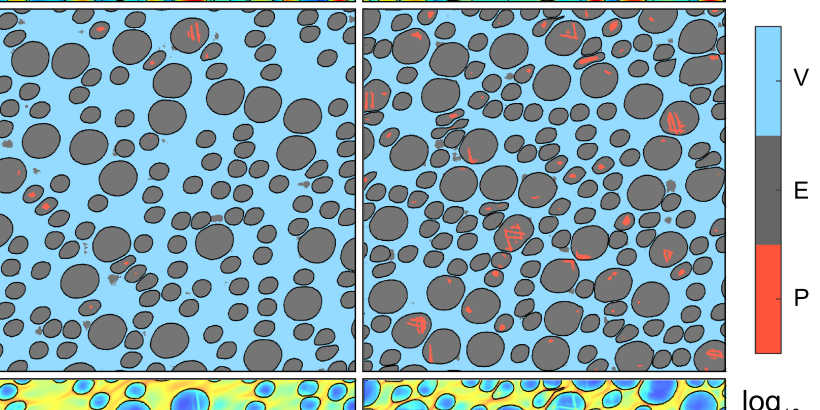

$\log _{10}$

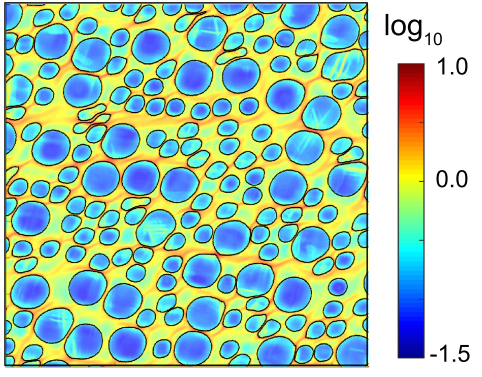

$\gamma=1.0$

Figure 9. Effect of the garnet proportion. Enlargement $\left(5 \mathrm{~cm}^{2}\right.$ in the center of the model) of the results obtain after a shear strain of 1 for different proportion of garnet (from left to right: 1, 20, 40, and 55\%). Input parameters are the same for all the models such as $\dot{\varepsilon}_{\mathrm{BG}}=10^{-12} \mathrm{~s}^{-1}, 2.0 \mathrm{GPa}$, and $T=550{ }^{\circ} \mathrm{C}$. Top line: second invariant of the shear stress. Middle line: Dominant rheological model (legend as in Figures 6-8). Bottom line: Accumulated strain.

local stresses in garnet and local strain rates in omphacite) is additive and leads to an increase of the effective stress of the whole rock with garnet proportions (Figure 10).

The effect of garnet content variations appears as important as the effect of background strain rate variations (Figure 10). At a given strain rate of $10^{-12} \mathrm{~s}^{-1}$, the effective stress increases from $\sim 350$ ( $0 \%$ of garnet) to $~ 580$ $\mathrm{MPa}$ in the model presenting 55\% of garnet (Figure 10a). Important also is to note that considering $100 \%$ of garnet and this particular strain rate value would lead to an effective stress of $1.043 \mathrm{GPa}$ (see Figure S2). For comparison, Figures 10b and 10c present the variation of the effective stresses as a function of the strain rate for cases with $10 \%$ and $55 \%$ of garnet content, respectively. When the omphacite matrix is viscous (i.e., for $\dot{\varepsilon}_{\mathrm{BG}}<10^{-10} \mathrm{~s}^{-1}$ ) an increase of 1 order of magnitude in strain rate produces almost the same effect than an increase in garnet proportion from 0 to $50 \%$. Another interesting result is that, at high strain rate $\left(\geq 10^{-10} \mathrm{~s}^{-1}\right)$, the entire sample yields and the presence of shear bands produced by stress heterogeneities induces softening (Figures 10b and 10c). The development of stress heterogeneities is explained by the use, in our model, of different flow law parameters for garnet and omphacite. The yield criterion is then reached in garnet crystals slightly before than in omphacite.

In conditions where omphacite flows, an increase in rigid garnet content (i.e., strong phase) results in an increase of the effective stress. In conditions where both omphacite and garnet reach the yield criterion, whole rock fracturing occurs. For homogeneous deformation, all phases have a similar yield stress that is equal to the effective stress (as for a mono-mineralic sample, dashed lines in Figures 10b and 10c). However, the occurrence of shear zones leads to heterogeneous deformation, which in turn, induces 

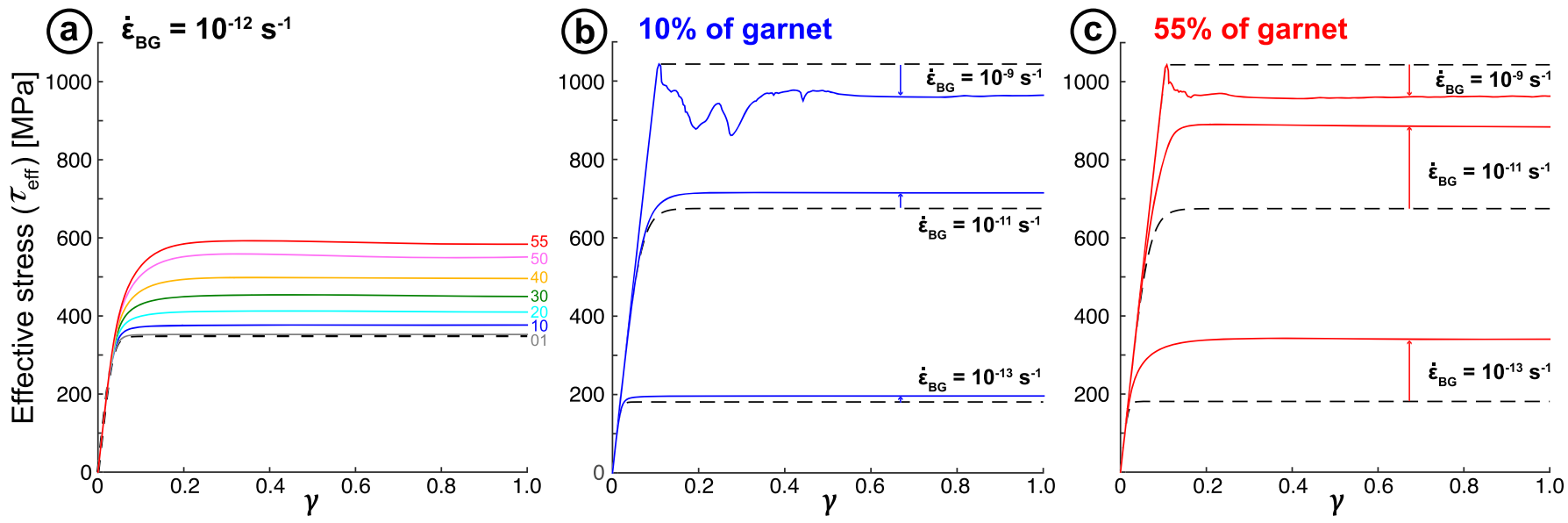

Figure 10. Effective stress evolution for different simulations as a function of the shear strain $(\gamma)$ (a) at a fixed background strain rate of $10^{-12} \mathrm{~s}^{-1}$ for different garnet proportion (different colors). (b) At a garnet proportion fixed at 10\% for three different strain rates. (c) At a garnet proportion fixed at 55\% for three different strain rates. For comparison, the effective stress evolution for pure omphacite at the corresponding strain rates is also shown in dashed lines.

structural softening. Hence, in this condition, even when composed of stronger material, the effective rock strength of an eclogite is lower than in case of pure omphacite.

\section{Discussion}

These results allow to discuss the rheological behavior of eclogites at HP-LT conditions and to constrain the range of values where the expression of frictional plasticity (e.g., faults and fractures) can be observed in eclogites. With such models, it is possible to predict the regime of deformation, and also how deformation evolves with time depending on background strain rates and garnet proportion. In nature, however, if garnet content can be directly measured in samples and assuming it remained constant, the background strain rate is unfortunately not accessible. Thanks to such parametric study, a careful analysis of deformation in eclogitic rocks could inform us on the strain rate magnitudes that caused deformation and on the implications of frictional yielding in HP-LT rocks. However, some points deserve to be discussed.

\subsection{Rheology of HP-LT Rock-Forming Minerals}

In our models, we used the omphacite dislocation creep flow law from Zhang et al. (2006). We took these parameters (Table 1) as they constitute, for us, the most representative ones for polycrystalline omphacite ( $\sim$ half jadeite and half diopside in composition). A computation of the effective stresses using equation (7) at $550^{\circ} \mathrm{C}$ and for strain rates of interest (between $10^{-14}$ and $10^{-8} \mathrm{~s}^{-1}$ ) shows that the use of this law is appropriate for our study (see supporting information Figure S5). The effective flow stresses obtained are indeed in agreement with the range of values obtained with many other flow laws (Avé Lallement, 1978; Boland \& Tullis, 1986; Kirby \& Kronenberg, 1984; Kollé \& Blacic, 1983; Raterron \& Jaoul, 1991; Stöckhert \& Renner, 1998) and are especially close to the latest experimental data (e.g., Moghadam et al., 2010; Orzol et al., 2006). Moreover, three data sets were discarded. In Moghadam et al. (2010), results for Di25Jd75 are far from their four other flow laws. The data for Jadeite from Stöckhert and Renner (1998) strongly differ from the data of Orzol et al. (2006). The data for Diopside from Avé Lallement (1978), which corresponds to our oldest data, predict effective stress 2 times lower than the others law. Excluding these three data, the data set of Zhang et al. (2006) is, with the data from Orzol et al. (2006), the one that exhibits the weakest omphacite. By using these data, our results therefore reduce the part of the brittle deformation that would be observed by using the other laws. Our conclusions on possible strain rate values that can lead to brittle features would be even more drastic using the other data sets.

For garnet, we used the flow law from Ji and Martignole (1994) as it appears also the most appropriate for our study. The number of experimental data for garnet is indeed limited and/or most of the time dedicated to higher-pressure-temperature values (e.g., Katayama \& Karato, 2008; Li et al., 2006; Mei et al., 2010). Moreover, dislocation creep in garnet is never activated in the $P-T$ conditions of our models. Our results 

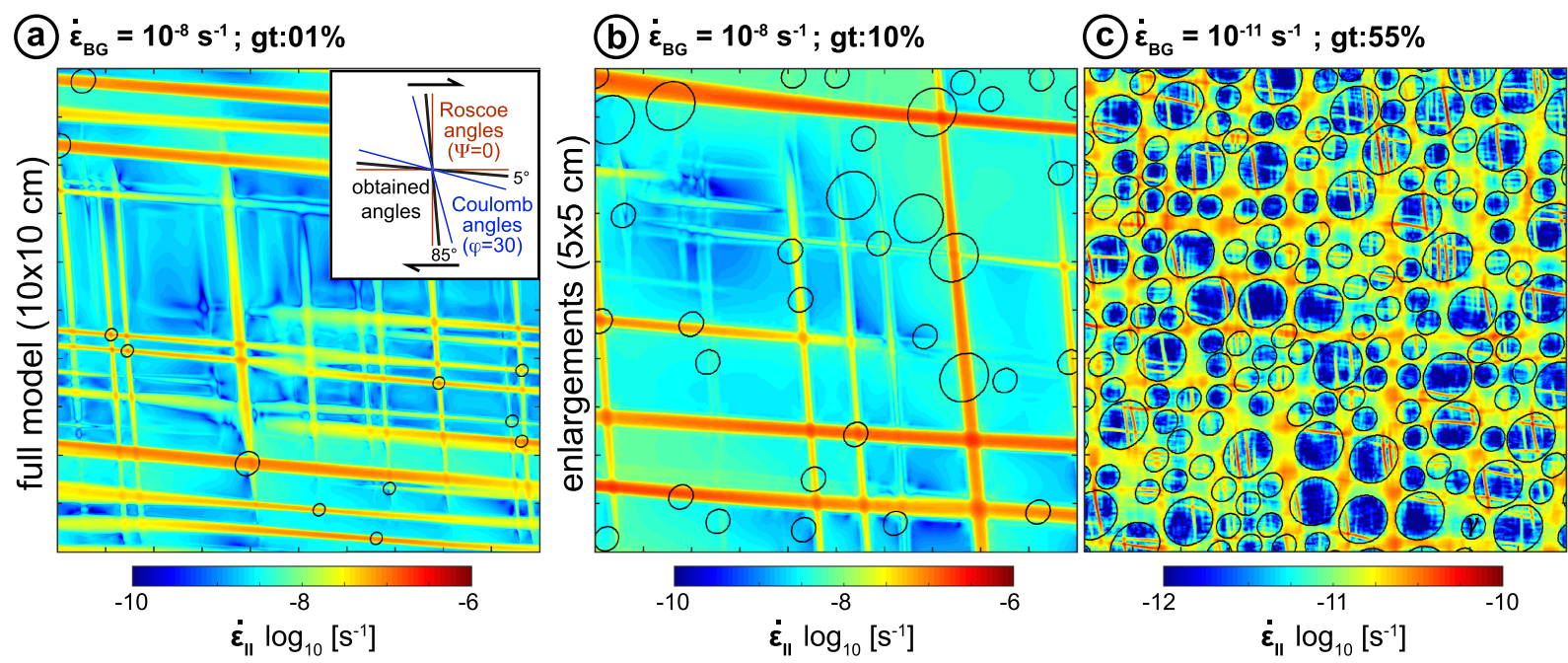

Figure 11. Second invariant of the strain rate highlighting fractures orientations. Garnet crystals are outlined in black. (a) Full size model snapshot taken just after whole rock fracturing. Inset: comparison of the obtained angle (black lines) with theoretical Roscoe angles (red lines, where $\Psi$ corresponds to the dilation angle) and Coulomb angles (blue lines, where $\varphi$ corresponds to the friction angle). Note that the shear band nucleation is controlled by the position of garnet crystals. (b) Zoom in a model presenting whole rock fracturing with $10 \%$ of garnet. The snapshot is taken just after yielding and illustrates how fractures crosscut both garnet inclusions and omphacite matrix. (c) Zoom in a model presenting garnet fracturing in a ductile matrix after a shear strain $(\gamma)$ of 0.2 .

will remain valid, whatever the flow law used for garnet, as long as the flow stress will be much higher than the yield stress predicted by the Drucker-Prager law. In addition, by performing the same diagram than in Figure 4 for an eclogitic rock (Jin et al., 2001; Zhang \& Green, 2007; see supporting information Figure S6) it is reassuring to note that the mechanical behavior corresponds well to a mix between the selected flow laws for garnet and omphacite.

Another important point is that other deformation mechanisms such as diffusion creep or dissolution-precipitation creep are not included in this study. One reason is that, as discussed previously (section 2.1.2.), in our $P$ - $T$ conditions and for the initial proposed grain size, diffusion creep is not activated. Moreover, it will require a supplementary law for grain size evolution and would necessitate an additional parameterization. Dissolution-precipitation creep is often evoked for $P$ - $T$ conditions considered here (e.g., Smit et al., 2011; Stöckhert, 2002; Wassman \& Stöckhert, 2013), but the current lack of data does not allow for any practical implementation. Our conclusions therefore need to be moderated, and the applicability of our results restricted to the cases where pressure-solution mechanisms are not microstructurally evidenced. Finally, it can be noticed that our models also do not entirely consider the garnet size (only two sizes for garnet crystals are here considered). They also do not integrate possible retrograde processes and/or effect of fluid-assisted recrystallization and annealing that could probably overprint deformation that occurred at metamorphic peak conditions. Our results are thus valid (and can be compared with natural examples) in cases where the diagnosed deformation is contemporaneous of the metamorphic peak conditions, in absence of fluid-assisted recrystallization, and where deformation mechanisms cannot be related to pressuresolution processes. The Monviso mylonitized eclogites from Lago Superiore (see Figure 1) appear to be a good example where fracturing leading to eclogite breccias occurred (at least for the first stages) before the arrival of fluids (Locatelli et al., 2018).

\subsection{About the Brittle Behavior of Eclogites}

Our results are representative of the diversity in deformation patterns that can be observed in eclogitic rocks (e.g., Fountain et al., 1994; see also Figure 1). Depending on strain rate and garnet proportion (Figure 5a), it is possible to explain the deformation mode distribution of (1) intact garnet in ductile omphacite matrix, (2) fractured garnet in ductile omphacite matrix, and (3) entire rock fracturing. Whether during the entire fracturing of the rock or during the fracturing of the garnet crystals alone, fracturing always occurs with the same orientation (Figure 11). Even if garnet rotate (Figure 11c), fracturing occurs coherently with the same orientations. Fractures initiate at rheological contrasts between garnet crystals and omphacite matrix when 

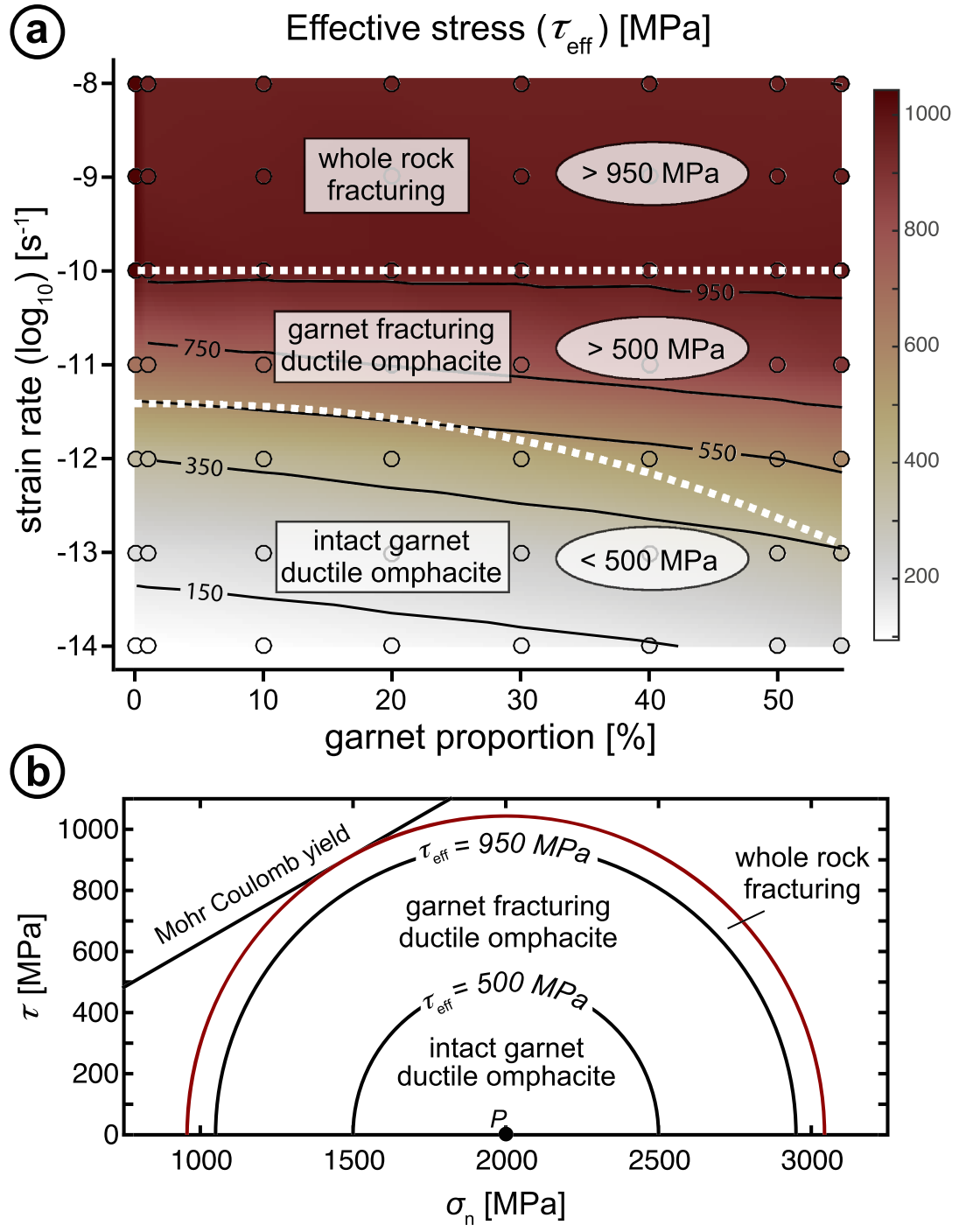

Figure 12. (a) Average of the effective stress computed from all models depending on the imposed background strain rate and the garnet proportion. Dots correspond to the values directly extracted from the performed numerical simulations (averaged between a $\gamma$ of 0.5 and 1.0. Color map is simply obtained by interpolation. White dotted line corresponds to the limit of the deformation mode (see Figure 5a). (b) Mohr diagram (normal stress vs shear stress) replacing the state of stress corresponding to the different deformation modes. $P$ corresponds to the total pressure. Red line displays the maximum effective stress (at Mohr-Coulomb failure criteria).

the yield stress is reached. This is in agreement with previous studies of plastic shear zone localization around rigid inclusions (e.g., Misra \& Mandal, 2007). The orientations of the shear bands are with an angle of $40^{\circ}$ compared to principal stress $\sigma_{1}$. This is in the range of the acceptable values (e.g., Kaus, 2010), between Roscoe angles ( $\left(45^{\circ}\right.$ compared to $\left.\sigma_{1}\right)$ and Coulomb angles $\left(30^{\circ}\right.$ compare to $\left.\sigma_{1}\right)$. Note also the resemblance with healed fracture patterns recorded in natural samples (Figures $1 \mathrm{~b}$ and $1 \mathrm{c}$ ).

\subsection{Consequences for Strain Rate Estimates}

One important conclusion of our study (Figure 5a) reveals that the observation of brittle features in eclogites does not necessarily signifies that eclogites have undergone extreme strain rate. Whole rock fracturing can occur from strain rates as low as $10^{-10} \mathrm{~s}^{-1}$, which is far from seismic strain rates $\geq 1 \mathrm{~s}^{-1}$ (e.g., Burov, 2011). Intermediate strain rates, between seismic and ductile patterns (from $10^{-10} \mathrm{~s}^{-1}$ up to $10^{-2} \mathrm{~s}^{-1}$ ), span a range expected to encompass episodic tremors or slow slip events (e.g., Angiboust et al., 2015; Rowe et al., 2011). It remains unknown whether slow earthquakes or nonvolcanic tremors can form during shearing of 
(a) dynamic pressure
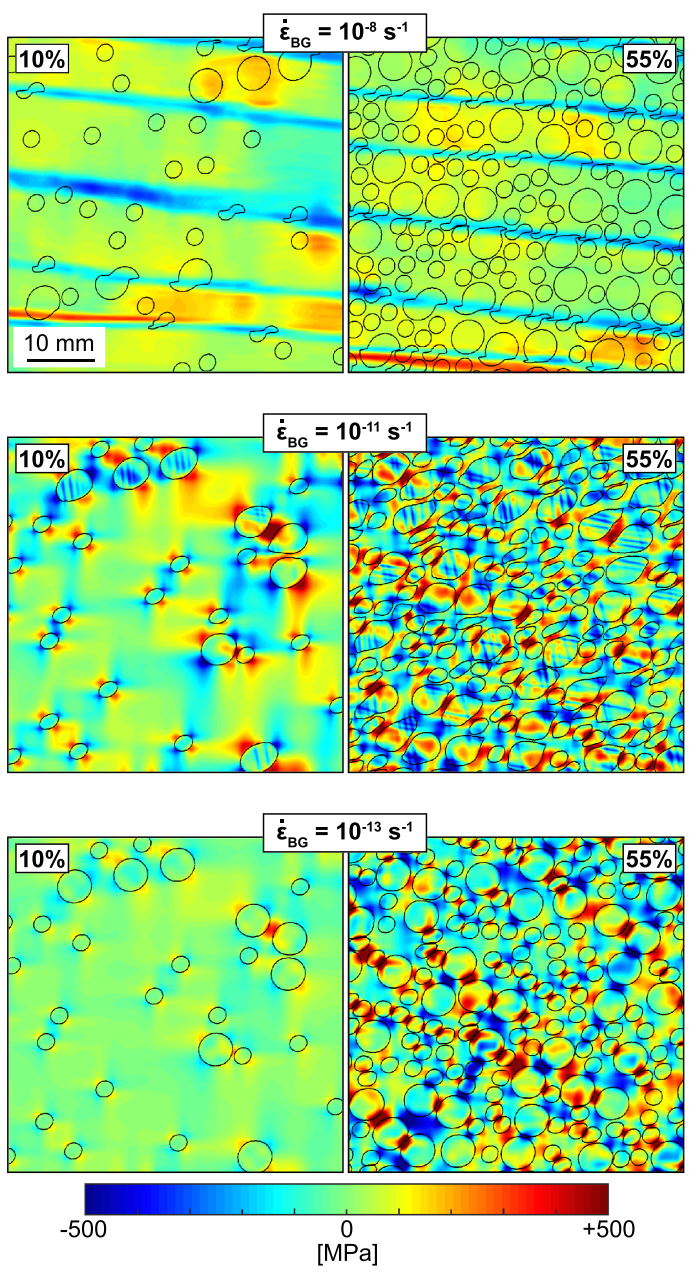

(b) state of stresses
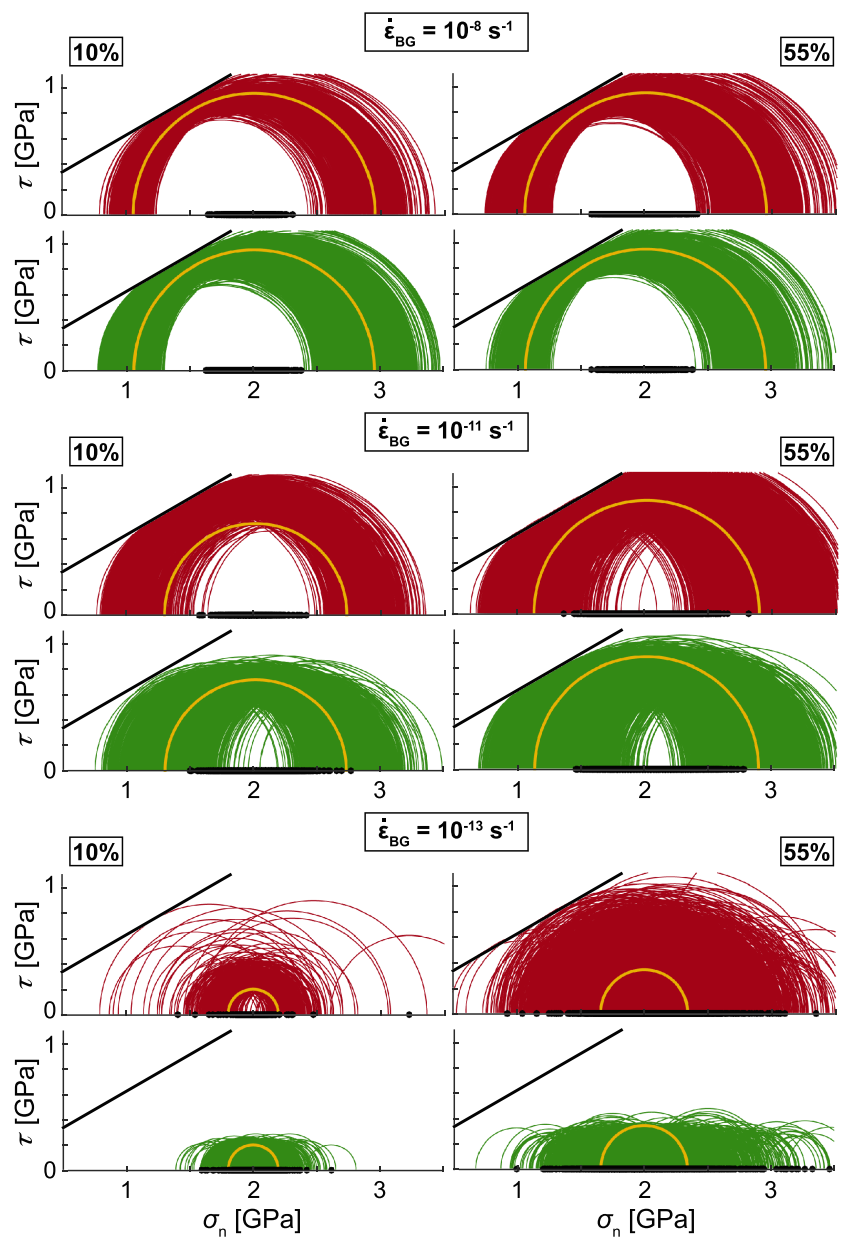

Figure 13. (a) Dynamic pressure for different models after a shear strain of 1 . Figures correspond to enlargements ( $5 \mathrm{~cm}^{2}$ in the model center). (b) Mohr diagram (normal stress $\sigma_{\mathrm{n}}$ vs shear stress $\tau$ ) presenting the state of stresses extracted for garnet crystals (in red) and omphacite (in green) from the six simulations presented in Figure 13a. $\sigma_{\mathrm{n}}$ and $\tau$ are computed from the total pressure and the second invariant of stresses extracted from the model (1 mesh over 10) together with the nature of the material (garnet or omphacite). Yellow half circle corresponds to the effective stress value (computed as for Figure 12a). Black dots correspond to the total pressure.

eclogitized mafic crust (e.g., Figure 1a). If some slow slip events and tremors do form from the failure of rigid material in a weaker matrix (e.g., Fagereng et al., 2014), one could consider that some of our models fill the conditions required to trigger such mechanical instabilities (despite the absence of fluids in our modeling approach). Moreover, observation of fractured garnet alone is not necessarily a proof of high strain rate as it can occurs at strain rate as low as $10^{-12}$ to $10^{-13} \mathrm{~s}^{-1}$ if the garnet proportion is high $(\geq 40 \%)$. Caution therefore deserves to be taken when attributing brittle failure evidences to tectonic slip at seismic or subseismic strain rates.

\subsection{Consequences of High State of Stresses at HP-LT Conditions}

In the presented simulations, the effective stress computed for the whole rock rapidly reaches a steady value (see Figure 5b). A value of an averaged effective stresses can therefore be computed through time (for $\gamma$ taken between 0.5 and 1 , for instance) and considered as representative of a steady state effective stress sustained by the rock. A synthesis of all these averaged effective stresses is presented in Figure 12a together with the different fields of deformation modes. This figure shows that the deformation mode, which can be observed in the rocks, can constitute an indicator of the state of stress. When whole rock fracturing occurs (i.e., when $\dot{\varepsilon}_{\mathrm{BG}} \geq 10^{-10} \mathrm{~s}^{-1}$ ), in our background $P$-T conditions (i.e., at $2.0 \mathrm{GPa}$ and $550^{\circ} \mathrm{C}$ ), the effective stress remains 
high and $>950 \mathrm{MPa}$. In the same way, evidence of garnet fracturing at $2.0 \mathrm{GPa}$ and $550{ }^{\circ} \mathrm{C}$ can be interpreted as a state of stress higher than $500 \mathrm{MPa}$. Figure 12b summarizes in a Mohr diagram the interpretation that can be done, in terms of state of stress, from the observation of the deformation mechanism evidenced in eclogitic rocks. Hence, in the $P$ - $T$ conditions considered here, we can conclude that for fluid-absent conditions structures owing to brittle deformation can be attributed to a differential stress $\left(\sigma_{1}-\sigma_{3}\right)$ higher than 1 $\mathrm{GPa}$. These values are in line with recent estimates by Scambelluri et al. (2017) from a dry eclogitized metagabbro from the Western Alps crosscut by paleo-seismic shear fractures (pseudotachylytes).

\subsection{What About the Pressure Distribution?}

The presence, in our models, of different materials with different rheological properties necessarily leads to local variations of the pressure field (i.e., dynamic pressures). Dynamic pressure is defined as the difference between the (total) pressure and the background pressure. This dynamic pressure is illustrated in Figure 13a for different background strain rates and garnet proportions. Our results are in agreement with previous studies concerning the pressure variation existing around inclusions (e.g., Moulas et al., 2014; Schmid \& Podladchikov, 2003) and with the fact that the development of brittle structures is associated with local pressure decrease (e.g., Mancktelow, 2006). The magnitude of pressure variations often exceeds 500 MPa even if the dynamic pressure distribution is centered around 0 . It means that (total) pressure estimates that could be extracted from garnet-omphacite association do not necessarily correspond to the background pressure (here of $2 \mathrm{GPa}$ ) but deviates, in most of the cases, from this average value (blue and red colors in Figure 13a). Figure 13b also shows how the state of stresses is distributed between garnet crystals and omphacite matrix for the models presented in Figure 13a. This also shows that (total) pressure variations (dispersion of black dots in Figure 13b) are higher at low background strain rates than at high background strain rates. This effect is amplified when the garnet content increases. At higher strain rates, the state of stresses is much more homogeneous and close to the effective stress (yellow half-circle in Figure 13b) between garnet and omphacite and also for each phase taken separately. Consequently, variations in (total) pressure are less important at high background strain rate. Moreover, these pressures are associated with effective stresses close to the yield stress limitation. Hence, homogeneous pressure values that can be obtained by barometry estimates (i.e., within the error range of barometric estimations) do not necessary reflect low differential stresses. Our results show that quasi-homogeneous pressures (i.e., $\pm 300 \mathrm{MPa}$, Figure 13b) can also be the result of large stresses, especially when the stress state is close to the yield stress.

\section{Conclusion}

Our results show that, in the conditions of our models, frictional deformation of entire eclogite rock can occur under HP-LT conditions for strain rate values even smaller than those generally expected for seismic events. Garnet modal proportion plays an important role, especially for high garnet content (>25\%), and this effect can be as important as the effect of the strain rate. Consequently, evidence of brittle deformation in garnet crystals, as witnesses of important stresses sustained by rocks, can be crucial clues for our appraisal of the rheology of HP-LT rocks. Indeed, following our results, the stress levels sustained by such rocks (at a background pressure of $2 \mathrm{GPa}$ ) can be as high as $\sim 1 \mathrm{GPa}$ for an eclogite entirely fractured and up to $\sim 500 \mathrm{MPa}$ for rocks presenting fractured garnet.

Acknowledgments

P. Y. thanks the INSU SYSTER program and the IUF that funded a part of this work. M. Baïsset and J. Quinteros are acknowledged for insightful discussions. J. Precigout and an anonymous reviewer are also thanked for their suggestions that improved the quality of the manuscript. This is IPGP contribution 4046. S. A. acknowledges the IDEX research chair 16C538. Data used in this work were produced by solving the equations provided in the text (section 2.1). The related 2D thermo-mechanical code is available upon request from the corresponding author.

\section{References}

Agard, P., Yamato, P., Jolivet, L., \& Burov, E. (2009). Exhumation of oceanic blueschists and eclogites in subduction zones: Timing and mechanisms. Earth-Science Reviews, 92(1-2), 53-79. https://doi.org/10.1016/j.earscirev.2008.11.002

Angiboust, S., Agard, P., Raimbourg, H., Yamato, P., \& Huet, B. (2011). Subduction interface processes recorded by eclogite-facies shear zones (Monviso, W. Alps). Lithos, 127(1-2), 222-238. https://doi.org/10.1016/j.lithos.2011.09.004

Angiboust, S., Agard, P., Yamato, P., \& Raimbourg, H. (2012). Eclogite breccias in a subducted ophiolite: A record of intermediate-depth earthquakes? Geology, 40(8), 707-710. https://doi.org/10.1130/G32925.1

Angiboust, S., Kirsch, J., Oncken, O., Glodny, J., Monié, P., \& Rybacki, E. (2015). Probing the transition between seismically coupled and decoupled segments along an ancient subduction interface. Geochemistry, Geophysics, Geosystems, 16, 1905-1922. https://doi.org/ $10.1002 / 2015 G C 005776$

Angiboust, S., Langdon, R., Agard, P., Waters, D., \& Chopin, C. (2012). Eclogitization of the Monviso ophiolite (W. Alps) and implications on subduction dynamics. Journal of Metamorphic Geology, 30(1), 37-61. https://doi.org/10.1111/j.1525-1314.2011.00951.x

Austrheim, H., \& Andersen, T. B. (2004). Pseudotachylytes from Corsica: Fossil earthquakes from a subduction complex. Terra Nova, 16(4), 193-197. https://doi.org/10.1111/j.1365-3121.2004.00551.x

Austrheim, H., \& Boundy, T. M. (1994). Pseudotachylytes generated during seismic faulting and eclogitization of the deep crust. Science, 265(5168), 82-83. https://doi.org/10.1126/science.265.5168.82 
Avé Lallement, H. G. (1978). Experimental deformation of diopside and websterite. Tectonophysics, 48(1-2), 1-27. https://doi.org/10.1016/ 0040-1951(78)90083-5

Bascou, J., Barruol, G., Vauchez, A., Mainprice, D., \& Egydio-Silva, M. (2001). EBSD-measured lattice-preferred orientations and seismic properties of eclogites. Tectonophysics, 342(1-2), 61-80. https://doi.org/10.1016/S0040-1951(01)00156-1

Behr, W. M., Kotowski, A. J., \& Ashley, K. T. (2018). Dehydration-induced rheological heterogeneity and the deep tremor source in warm subduction zones. Geology, 46(5), 475-478. https://doi.org/10.1130/G40105.1

Boland, J. N., \& Tullis, T. E. (1986). Deformation behavior of wet and dry clinopyroxenite in the brittle to ductile transition region. In B. E. Hobbs, \& H. C. Heard (Eds.), Mineral and rock deformation: Laboratory Studies, Geophys. Monogr. Ser., vol. 36, (pp. 35-49). Washington, D.C.: AGU. https://doi.org/10.1029/GM036p0035

Boundy, T. M., Fountain, D. M., \& Austrheim, H. (1992). Structural development and petrofabrics of eclogite facies shear zones, Bergen Arcs, western Norway: Implications for deep crustal deformational processes. Journal of Metamorphic Geology, 10(2), 127-146. https:// doi.org/10.1111/j.1525-1314.1992.tb00075.x

Burov, E. B. (2011). Rheology and strength of the lithosphere. Marine and Petroleum Geology, 28(8), 1402-1443. https://doi.org/10.1016/j. marpetgeo.2011.05.008

Byerlee, J. (1978). Friction of rocks. Pure and Applied Geophysics, 116(4-5), 615-626. https://doi.org/10.1007/BF00876528

Duretz, T., Schmalholz, S. M., Podladchikov, Y. Y., \& Yuen, D. A. (2014). Physics-controlled thickness of shear zones caused by viscous heating: Implications for crustal shear localization. Geophysical Research Letters, 41, 4904-4911. https://doi.org/10.1002/2014GL060438

Ernst, W. G., Hacker, B. R., \& Liou, J. G. (2007). Petrotectonics of ultrahigh-pressure crustal and upper-mantle rocks-Implications for Phanerozoic collisional orogens, The Geological Society of America Special Paper, (Vol. 433, pp. 27-49).

Fagereng, A., Hillary, G. W., \& Diener, J. F. (2014). Brittle-viscous deformation, slow slip, and tremor. Geophysical Research Letters, 41, 4159-4167. https://doi.org/10.1002/2014GL060433

Fossen, H., \& Cavalcante, G. C. G. (2017). Shear zones - A review. Earth-Science Reviews, 171, 434-455. https://doi.org/10.1016/j. earscirev.2017.05.002

Fountain, D. M., Boundy, T. M., Austrheim, H., \& Rey, P. (1994). Eclogite-facies shear zones-Deep crustal reflectors? Tectonophysics, 232(1-4), 411-424. https://doi.org/10.1016/0040-1951(94)90100-7

García-Casco, A., Torres-Roldan, R. L., Millan, G., Monié, P., \& Schneider, J. (2002). Oscillatory zoning in eclogitic garnet and amphibole, Northern Serpentinite Melange, Cuba: A record of tectonic instability during subduction? Journal of Metamorphic Geology, 20(6), 581-598. https://doi.org/10.1046/j.1525-1314.2002.00390.x

Gerya, T. V., \& Yuen, D. A. (2003). Characteristics-based marker-in-cell method with conservative finite-differences schemes for modeling geological flows with strongly variable transport properties. Physics of the Earth and Planetary Interiors, 140(4), 293-318. https://doi.org/ 10.1016/j.pepi.2003.09.006

Godard, G., \& van Roermund, H. L. (1995). Deformation-induced clinopyroxene fabrics from eclogites. Journal of Structural Geology, 17(10), 1425-1443. https://doi.org/10.1016/0191-8141(95)00038-F

Groppo, C., \& Castelli, D. (2010). Prograde P-T evolution of a lawsonite eclogite from the Monviso meta-ophiolite (Western Alps): Dehydration and redox reactions during subduction of oceanic FeTi-oxide gabbro. Journal of Petrology, 51(12), 2489-2514. https://doi. org/10.1093/petrology/egq065

Hacker, B. R., Peacock, S. M., Abers, G. A., \& Holloway, S. D. (2003). Subduction factory. 2. Are intermediate-depth earthquakes in subducting slabs linked to metamorphic dehydration reactions? Journal of Geophysical Research, 108(B1), 2030. https://doi.org/10.1029/ 2001JB001129

Hertgen, S., Yamato, P., Morales, L. F. G., \& Angiboust, S. (2017). Evidence for brittle deformation events at eclogite-facies P-T conditions (example of the Mt. Emilius klippe, Western Alps). Tectonophysics, 706-707, 1-13. https://doi.org/10.1016/j.tecto.2017.03.028

Hier-Majumder, S., Mei, S., \& Kohlstedt, D. L. (2005). Water weakening of clinopyroxenite in diffusion creep. Journal of Geophysical Research, 110, B07406. https://doi.org/10.1029/2004JB003414

Incel, S., Hilairet, N., Labrousse, L., John, T., Deldicque, D., Ferrand, T. P., et al. (2017). Laboratory earthquakes triggered during eclogitization of lawsonite-bearing blueschist. Earth and Planetary Science Letters, 459, 320-331. https://doi.org/10.1016/j.epsl.2016.11.047

Jamtveit, B., Austrheim, H., \& Putnis, A. (2016). Disequilibrium metamorphism of stressed lithosphere. Earth-Science Reviews, 154, 1-13. https://doi.org/10.1016/j.earscirev.2015.12.002

Jessell, M. W., Bons, P. D., Griera, A., Evans, L. A., \& Wilson, C. J. L. (2009). A tale of two viscosities. Journal of Structural Geology, 31(7), 719-736. https://doi.org/10.1016/j.jsg.2009.04.010

Ji, S., \& Martignole, J. (1994). Ductility of garnet as an indicator of extremely high temperature deformation. Journal of Structural Geology, 16(7), 985-996. https://doi.org/10.1016/0191-8141(94)90080-9

Jin, Z. M., Zhang, J., Green, H. W. II, \& Jin, S. (2001). Eclogite rheology: Implications for subducted lithosphere. Geology, 29(8), 667-670. https://doi.org/10.1130/0091-7613(2001)029<0667:ERIFSL>2.0.CO;2

John, T., \& Schenk, V. (2006). Interrelations between intermediate-depth earthquakes and fluid flow within subducting oceanic plates: Constraints from eclogite facies pseudotachylytes. Geology, 34(7), 557-560. https://doi.org/10.1130/G22411.1

Jung, H., Green, H. W. II, \& Dobrzhinetskaya, L. F. (2004). Intermediate-depth earthquake faulting by dehydration embrittlement with negative volume change. Nature, 428(6982), 545-549. https://doi.org/10.1038/nature02412

Katayama, I., \& Karato, S. I. (2008). Effects of water and iron content on the rheological contrast between garnet and olivine. Physics of the Earth and Planetary Interiors, 166(1-2), 57-66. https://doi.org/10.1016/j.pepi.2007.10.004

Kaus, B. J. P. (2010). Factors that control the angle of shear bands in geodynamic numerical models of brittle deformation. Tectonophysics, 484(1-4), 36-47. https://doi.org/10.1016/j.tecto.2009.08.042

Kaus, B. J. P., \& Podladchikov, Y. Y. (2006). Initiation of localized shear zones in viscoelastoplastic rocks. Journal of Geophysical Research, 111, B04412. https://doi.org/10.1029/2005JB003652

Kirby, S. H., \& Kronenberg, A. K. (1984). Deformation of clinopyroxenite: Evidence for a transition in flow mechanisms and semibrittle behavior. Journal of Geophysical Research, 89(B5), 3177-3192. https://doi.org/10.1029/JB089iB05p03177

Kollé, J. J., \& Blacic, J. D. (1983). Deformation of single-crystal clinopyroxenes: 2. Dislocation-controlled flow processes in Hedenbergite. Journal of Geophysical Research, 88(B3), 2381-2393. https://doi.org/10.1029/JB088iB03p02381

Li, L., Long, H., Raterron, P., \& Weidner, D. (2006). Plastic flow of pyrope at mantle pressure and temperature. American Mineralogist, 91(4), 517-525. https://doi.org/10.2138/am.2006.1913

Locatelli, M., Verlaguet, A., Agard, P., Federico, L., \& Angiboust, S. (2018). Intermediate-depth brecciation along the subduction plate interface (Monviso eclogite, W. Alps). Lithos, 320, 378-402. https://doi.org/10.1016/j.lithos.2018.09.028

Mancktelow, N. S. (2006). How ductile are ductile shear zones? Geology, 34(5), 345-348. https://doi.org/10.1130/G22260.1 
Mancktelow, N. S. (2008). Tectonic pressure: Theoretical concepts and modelled examples. Lithos, 103(1-2), 149-177. https://doi.org/ 10.1016/j.lithos.2007.09.013

Mauler, A., Godard, G., \& Kunze, K. (2001). Crystallographic fabrics of omphacite, rutile and quartz in Vendée eclogites (Armorican Massif, France). Consequences for deformation mechanisms and regimes. Tectonophysics, 342(1-2), 81-112. https://doi.org/10.1016/S00401951(01)00157-3

Mei, S., Suzuki, A. M., Kohlstedt, D. L., \& Lili, X. (2010). Experimental investigation of the creep behavior of garnet at high temperatures and pressures. Journal of Earth Science, 21(5), 532-540. https://doi.org/10.1007/s12583-010-0127-8

Menegon, L., Pennacchioni, G., Malaspina, N., Harris, K., \& Wood, E. (2017). Earthquakes as precursors of ductile shear zones in the dry and strong lower crust. Geochemistry, Geophysics, Geosystems, 18, 4356-4374. https://doi.org/10.1002/2017GC007189

Misra, S., \& Mandal, N. (2007). Localization of plastic zones in rocks around rigid inclusions: Insights from experimental and theoretical models. Journal of Geophysical Research, 112, B09206. https://doi.org/10.1029/2006JB004328

Moghadam, R. H., Trepmann, C. A., Stöckhert, B., \& Renner, J. (2010). Rheology of synthetic omphacite aggregates at high pressure and high temperature. Journal of Petroleum, 51(4), 921-945. https://doi.org/10.1093/petrology/egq006

Moulas, E., Burg, J. P., \& Podladchikov, Y. (2014). Stress field associated with elliptical inclusions in a deforming matrix: Mathematical model and implications for tectonic overpressure in the lithosphere. Tectonophysics, 631, 37-49.

Orzol, J., Stöckhert, B., Trepmann, C. A., \& Rummel, F. (2006). Experimental deformation of synthetic wet jadeite aggregates. Journal of Geophysical Research, 111, B06205. https://doi.org/10.1029/2005JB003706

Petrini, K., \& Podladchikov, Y. (2000). Lithospheric pressure-depth relationship in compressive regions of thickened crust. Journal of Metamorphic Geology, 18(1), 67-77. https://doi.org/10.1046/j.1525-1314.2000.00240.x

Philippot, P. (1987). “Crack seal” vein geometry in eclogitic rocks. Geodinamica Acta, 1(3), 171-181. https://doi.org/10.1080/ 09853111.1987.11105136

Philippot, P., \& van Roermund, H. L. (1992). Deformation processes in eclogitic rocks: Evidence for the rheological delamination of the oceanic crust in deeper levels of subduction zones. Journal of structural Geology, 14(8-9), 1059-1077. https://doi.org/10.1016/01918141(92)90036-V

Poliakov, A. N. B., Podladchikov, Y., \& Talbot, C. (1993). Initiation of salt diapirs with frictional overburdens: Numerical experiments. Tectonophysics, 228(3-4), 199-210. https://doi.org/10.1016/0040-1951(93)90341-G

Popov, A. A., \& Sobolev, S. V. (2008). SLIM3D: A tool for three-dimensional thermomechanical modeling of lithospheric deformation with elasto-visco-plastic rheology. Physics of the Earth and Planetary Interiors, 171(1-4), 55-75. https://doi.org/10.1016/j.pepi.2008.03.007

Raterron, P., \& Jaoul, O. (1991). High-temperature deformation of diopside single crystals. 1. Mechanical data. Journal of Geophysical Research, 96(14), 277-14 286.

Rowe, C. D., Meneghini, F., \& Moore, J. C. (2011). Textural record of the seismic cycle: Strain-rate variation in an ancient subduction thrust. Geological Society, London, Special Publications, 359(1), 77-95. https://doi.org/10.1144/SP359.5

Scambelluri, M., Pennacchioni, G., Gilio, M., Bestmann, M., Plümper, O., \& Nestola, F. (2017). Fossil intermediate-depth earthquakes in subducting slabs linked to differential stress release. Nature Geoscience, 10(12), 960-966. https://doi.org/10.1038/s41561-017-0010-7

Schmalholz, S. M., \& Fletcher, R. M. (2011). The exponential flow law applied to necking and folding of a ductile layer. Geophysical Journal International, 184(1), 83-89. https://doi.org/10.1111/j.1365-246X.2010.04846.x

Schmid, D. W., \& Podladchikov, Y. Y. (2003). Analytical solutions for deformable elliptical inclusions in general shear. Geophysical Journal International, 155(1), 269-288. https://doi.org/10.1046/j.1365-246X.2003.02042.x

Shi, F., Wang, Y., Yu, T., Zhu, L., Zhang, J., Wen, J., et al. (2018). Lower-crustal earthquakes in southern Tibet are linked to eclogitization of dry metastable granulite. Nature Communications., 9(1), 3483. https://doi.org/10.1038/s41467-018-05964-1

Smit, M. A., Scherer, E. E., John, T., \& Janssen, A. (2011). Creep of garnet in eclogite: Mechanisms and implications. Earth and Planetary Science Letters, 311(3-4), 411-419. https://doi.org/10.1016/j.epsl.2011.09.024

Stöckhert, B. (2002). Stress and deformation in subduction zone: Insight from the record of exhumed metamorphic rocks. Geological Society, London, Special Publications, 200(1), 255-274. https://doi.org/10.1144/GSL.SP.2001.200.01.15

Stöckhert, B., \& Renner, J. (1998). Rheology of crustal rocks at ultra-high pressure. In B. R. Hacker \& J. G. Liou (Eds.), When continents collide: Geodynamics and geochemistry of ultrahigh pressure rocks (pp. 57-95). Dordrecht: Kluwer. https://doi.org/10.1007/978-94-0159050-1_3

Trepmann, C. A., \& Stöckhert, B. (2002). Cataclastic deformation of garnet: a record of synseismic loading and postseismic creep. Journal of Structural Geology, 24(11), 1845-1856. https://doi.org/10.1016/S0191-8141(02)00004-4

Tsujimori, T., \& Ernst, W. G. (2014). Lawsonite blueschists and lawsonite eclogites as proxies for palaeo-subduction zone processes: A review. Journal of Metamorphic Geology, 32(5), 437-454. https://doi.org/10.1111/jmg.12057

Turcotte, D., \& Schubert, G. (2014). Geodynamics. Cambridge University Press. https://doi.org/10.1017/CBO9780511843877

Viete, D. R., Hacker, B. R., Allen, M. B., Seward, G. G. E., Tobin, M. J., Kelley, C. S., et al. (2018). Metamorphic records of multiple seismic cycles during subduction. Science Advances, 4(3), eaaq0234. https://doi.org/10.1126/sciadv.aaq0234

Wassman, S., \& Stöckhert, B. (2013). Rheology of the plate interface-Dissolution precipitation creep in high pressure metamorphic rocks. Tectonophysics, 608, 1-29. https://doi.org/10.1016/j.tecto.2013.09.030

Yamato, P., \& Brun, J. P. (2017). Metamorphic record of catastrophic pressure drops in subduction zones. Nature Geoscience, 10(1), 46-50. https://doi.org/10.1038/ngeo2852

Yamato, P., Duretz, T., May, D. A., \& Tartèse, R. (2015). Quantifying magma segregation in dykes. Tectonophysics, 660, 132-147. https://doi. org/10.1016/j.tecto.2015.08.030

Yamato, P., Tartèse, R., Duretz, T., \& May, D. A. (2012). Numerical modelling of magma transport in dykes. Tectonophysics, 526-529, 97-109 https://doi.org/10.1016/j.tecto.2011.05.015

Yang, J. J., Huang, M. X., Wu, Q. Y., \& Zhang, H. R. (2014). Coesite-bearing eclogite breccia: Implication for coseismic ultrahigh-pressure metamorphism and the rate of the process. Contributions to Mineralogy and Petrology, 167(6), 1013. https://doi.org/10.1007/s00410-0141013-7

Zhang, J., \& Green, H. W. (2007). Experimental investigation of eclogite rheology and its fabrics at high temperature and pressure. Journal of metamorphic Geology, 25(2), 97-115. https://doi.org/10.1111/j.1525-1314.2006.00684.x

Zhang, J., Green, H. W. II, \& Bozhilov, K. N. (2006). Rheology of omphacite at high temperature and pressure and significance of its lattice preferred orientations. Earth and Planetary Science Letters, 246(3-4), 432-443. https://doi.org/10.1016/j.epsl.2006.04.006 